\title{
The Effects of Bank Mergers on Corporate Information Disclosure
}

\author{
Qi Chen \\ Duke University, 100 Fuqua Drive, Durham, NC 27708, United States \\ Phone: 919-660-7753 / Fax: 919-660-7971 \\ qc2@duke.edu \\ Rahul Vashishtha* \\ Duke University, 100 Fuqua Drive, Durham, NC 27708, United States \\ Phone: 919-660-7755 / Fax: 919-660-7971 \\ rahul.vashishtha@duke.edu
}

This Draft: September 2015

\begin{abstract}
We use the mergers and acquisitions waves in the U.S. banking industry to study the effect of bank market structure on borrowers' disclosure. Applying a difference-in-differences approach to explore variations in the timing of bank mergers, we document significant increase in borrowing firms' disclosure when their lead banks engage in merger and acquisition activities. This effect is robust to a variety of controls for local economic conditions that may coincide with mergers, and is not concentrated in poorly performing banks or borrowers. Additional analyses suggest that the effect is stronger when mergers cause larger changes in banks' monitoring and financing of borrowers. To the extent that more public information disclosure is a key determinant for the development of public financial markets, our findings suggest a spillover effect from changes in bank market structure to the development of public financial markets.
\end{abstract}

JEL Classification: M40, G21, G32, D82

Keywords: Disclosure; Banks; Bank market structure; Mergers

We received helpful comments from Jeffrey Burks, Robert Bushman, Scott Liao, Russell Lundholm, Jacob Thomas, Frank Zhang, and participants at the Duke-UNC Fall Camp, University of British Columbia, Colorado Summer Accounting Conference (2014), and AAA Annual Meeting (2014). We thank Bill Mayew and Jimmy Lotterer from BestCalls.com for providing the conference call data. We thank Jeffrey Gao, Chris Calvin, You-il Park, and especially Huihao Yan for excellent research assistance.

*Corresponding author. 


\section{Introduction}

Availability of public information is a key determinant for efficient resource allocation in financial markets. A growing literature in accounting and finance seeks to understand how various features of a country's financial market structure and the associated institutional environment affect firms’ incentive to produce and disseminate public information (e.g., Ball, et al. (2000), Leuz, et al. (2003), Bushman, et al. (2004)). In this study, we extend this literature by providing evidence on how such incentive is affected by an important aspect of countries' institutional environment: the structure of banking market. Bank market structure plays a significant role in a country's overall financial development, both directly by affecting the nature and efficiency of banks' role as financial intermediaries, and indirectly by affecting the demand for products and services from alternative (public) financial markets. As such, understanding its economic consequences is of considerable interest to both researchers and regulators (Allen and Gale (2001)).

Specifically, we examine the effects of bank mergers and acquisitions (M\&As) in the U.S. on borrowers' voluntary disclosure of firm-specific information to public financial markets using microlevel data matching bank mergers to borrowers. Past three decades have witnessed significant waves of consolidation through M\&As in the U.S. banking industry (Pilloff (2004), Adams (2012)). ${ }^{1}$ Prior research argues that bank consolidation has fundamentally altered the structure of banking industry by affecting the scope and nature of banks' operations, their market power, and their ability to monitor and willingness to finance their borrowers. ${ }^{2}$ We explore the implications of these changes in bank market structure on borrowers’ voluntary disclosure behaviors. In doing so, our paper not only offers the first large sample evidence with micro-level data on how bank market structure affects

\footnotetext{
${ }^{1}$ Adams (2012) reports that over 10,000 mergers involving more than $\$ 7$ trillion in acquired assets have taken place in the U.S. banking industry since 1980, reducing the number of banks and thrifts operating in the U.S. by more than 60\%, from 19,069 in 1980 to 7,011 in 2010. Similarly, Pilloff (2004) notes that banking industry has become more concentrated, caused mostly by mergers of healthy institutions, with the 10 largest organizations holding more than 50 percent of banking assets in 2010, compared to 36\% in 2000 and only $13.5 \%$ in 1980.

2 See Berger et al. (1999), Amel et al. (2004), and DeYoung et al. (2009) for reviews on how bank mergers affect banks’ operations.
} 
firms' information environment, it also contributes to the literature by mitigating the endogeneity concerns associated with prior studies in this area. Prior evidence on the effects of financial market structure is based on cross-sectional comparison across countries, making it difficult to convincingly separate the effect of financial market structure from other country-specific institutional factors (e.g., legal regimes, economic development, etc.), and perhaps explaining the mixed evidence from this literature (see section 2). We mitigate the endogeneity concern by using borrower-lender level data and by exploring the effects of bank M\&As that changed bank market structure within a single country.

Whether increased consolidation through bank mergers can cause economically meaningful public information spillover through increased disclosure by borrowers is ex ante unclear from prior research. On the one hand, there are arguments that suggest that bank mergers can change banks' incentive to monitor and finance borrowers in ways that can lead to increased disclosure.

On the monitoring side, the disclosure increase could occur because of changes in the informational demands of external capital providers following changes in the nature of bank monitoring following bank mergers. Prior literature has recognized banks' role as delegated monitors because of their unique ability to cost effectively access and produce soft, private information about their borrowers (e.g., Diamond (1984, 1991), Fama (1985); James (1987)). The idea is that because dispersed public capital providers mainly rely on hard, public information for monitoring, they find it too costly to monitor and provide capital to firms for which much of the information is soft in nature. As a result, for such borrowers, public capital providers optimally delegate (at least part of) the monitoring effort to banks; this reduces public capital providers’ own demand for public disclosure for monitoring purposes (Ball et al. (2000); Vashishtha (2014)). More recent work argues that banking consolidation could fundamentally change the nature of bank monitoring by altering their organizational structures (e.g., Stein (2002); Berger et al. (2005)). Specifically, mergers result in larger, more complex, and hierarchical banking organizations that are 
less effective at collecting and processing soft information, but may be more efficient at processing hard information. To the extent banks' comparative advantage in monitoring primarily emanates from their ability to process soft information, following M\&As, public capital providers may no longer find it optimal to delegate the monitoring role to banks and may demand additional public disclosure to facilitate their own monitoring efforts. Moreover, to the extent much of the hard information can be efficiently collected through public disclosures, following M\&As, even banks may reduce their costly private information collection efforts and may instead rely more public disclosures (Gormley, Kim, and Martin (2012)).

On the financing side, bank mergers may create public information spillover by increasing bank' market power, enabling banks to raise the price of credit and/or limit the supply. This may cause borrowers to increase public disclosure to improve their access to alternative public financing (Diamond and Verrecchia (1991), Baiman and Verrecchia (1996)).

On the other hand there are arguments that suggest that bank mergers may lead to no change or even a decrease in borrowers' public disclosure. Literature on market for corporate control argues that mergers can act as a disciplining device for firms plagued by agency problems. As a result, monitoring effort may increase at banks that did not sufficiently monitor their borrowers prior to the mergers. This, in turn, may increase the willingness of public capital providers to delegate the monitoring role to banks, reducing their demand for public disclosure. Even on the financing side, bank mergers could increase the appeal of bank financing relative to public financing if mergers allow banks to generate efficiency gains through economies of scale, scope, or both, and banks pass on some of these gains to borrowers. In this scenario, borrowers may increase their reliance on bank financing, leading to no change or even decrease in public disclosure. To what degree are borrowers affected by the changed monitoring, market power, or efficiency gains is unclear ex ante. Therefore, whether bank mergers can cause any meaningful public information spillover, is ultimately an empirical question. 
Our analysis is based on a comprehensive sample of nearly 13,000 syndicated loan contracts where the lead lenders are commercial banks or bank holding companies and the borrowers are publicly traded companies in the U.S. exchanges with on-going lending relationship with their banks. We use a difference-in-differences design in which we compare changes in the disclosure of borrowers whose banks are involved in M\&As during their contract periods to contemporaneous changes in the disclosure of borrowers whose banks are not involved in M\&As. This design mitigates concerns about the confounding effect of unobservable cross-sectional differences across borrowers or time trends.

Using the incidence of conference calls as our main measure of disclosure, we find that borrowers significantly increase disclosure after their lending banks engage in M\&As. The increases are not concentrated in periods immediately after mergers; instead, the increases persist throughout post-merger periods. These effects are robust to the inclusion of controls for known determinants of disclosure and to alternative measures of disclosure based on earnings forecasts.

Under the assumption that changes in disclosure of borrowers affected by mergers and borrowers unaffected by mergers follow parallel trends in the absence of mergers, the above finding represents the causal effect of bank mergers (Angrist and Pischke (2009)). We verify that disclosure changes for both sets of borrowers are indeed statistically indistinguishable in the period prior to bank mergers. The key question, as in any DID setting, is whether the parallel trends would have continued in post-merger periods if the mergers had not happened. This assumption would be violated if bank mergers systematically coincide with any unobserved changes in firm characteristics or operating environments that also affect borrowers' disclosure decisions. If this is the case, the trends would diverge even without bank mergers.

We conduct a variety of tests to address several alternative explanations related to this concern. First, we examine whether our findings are driven by changes in local economic conditions that could drive both bank mergers and borrower disclosure. Prior work shows that banking 
deregulation, which removed regulatory hurdles to bank mergers, triggered significant local economic growth (e.g., Jayaratne and Strahan (1996)), raising the possibility that increased disclosure could be the result of improvements in local growth prospects. We conduct three analyses to address this concern. First, we show that our findings are robust to the inclusion of a comprehensive set of controls for location-level economic conditions. Second, we find that our results are robust to the inclusion of state-year or MSA-year interactive dummies that flexibly absorb the effect of any time-varying local level economic shocks. Finally, our findings are also robust to estimating the DID specification on a propensity score matched sample in which each treatment borrower (affected by bank mergers) is matched to an economically similar control borrower (unaffected by bank merger) from the same location. These findings suggest that the disclosure increase is unlikely to be driven by changes in local economic conditions.

Because one motivation for M\&As is acquisition of poorly performing banks, another possibility is that our results reflect the effect of poor financial health of banks that were acquired in mergers. Lo (2014) finds that borrowers of unhealthy banks increase disclosure to improve access to public financing. Moreover, if poor bank performance is a result of poor borrower performance, our results could be confounded by poor borrower performance. Prior studies, however, note that the U.S. banking consolidation has largely been driven by regulatory, technological, and competitive changes and most of the mergers involved healthy financial institutions (Pilloff (2004)). Furthermore, using a comprehensive set of proxies for bank and borrower performance, we find that the disclosure increase does not vary with these performance proxies and also manifests when banks and borrowers are in good health prior to mergers.

Collectively, we interpret the above findings as consistent with the idea that consolidation in banking industry causes increased information disclosure in public markets. Next, we conduct two additional analyses to shed light on the economic mechanisms that underlie the public information spillover effect. First, we explore the cross-sectional variation in the effects of bank mergers. We 
expect the disclosure increase to be driven by borrowers that are most affected by changes in the nature of banks' monitoring style and increase in banks' market power. Consistent with these predictions, we find evidence that disclosure increase is greater for borrowers: (i) who are more reliant on bank monitoring and financing prior to mergers; (ii) whose banks experience larger changes in organizational structures and hierarchy, and consequently, in the nature of monitoring following mergers; and, (iii) whose banks are involved in in-state mergers, which are more likely to increase banks' market power relative to out-of-state mergers.

Second, we further explore these channels by examining changes in borrowers' financing patterns following mergers. Consistent with the effect of banks' increased market power, we find evidence that borrowers reduce reliance on bank financing and increase reliance on public bond financing following mergers, and the disclosure increase is larger for borrowers that increase bond financing. At the same time, we also find that the disclosure increase is not limited to borrowers that increase public debt and also manifests for borrowers that do not increase public debt or decrease bank credit following mergers. The latter finding suggests that some borrowers increase disclosure to meet the changed informational demands for monitoring purposes. Collectively, these analyses suggest that the disclosure increase reflects borrowers' response to a changed monitoring environment as well as their desire to improve access to public financing following bank mergers.

Our study contributes to the literature on how macro-level institutional factors affect firms’ information environment by providing the first large sample, micro-level evidence on the causal effects of banking market consolidation on borrowers' voluntary disclosure. We find that increased consolidation in the U.S. banking industry has a spillover effect on the amount of information disclosed in public financial markets. Our results suggest that consolidation prompts borrowers to increase transparency to improve access to public financing and to meet the informational demands of external capital providers in a changed monitoring environment in which both public capital providers and banks rely more on public, hard information for monitoring purposes. 
Our study also contributes to the prior research on bank mergers. Mergers waves over the last three decades have fundamentally altered the structure of banking industry in US and a growing literature seeks to understand the economic consequences of this development. To the best of our knowledge, our study is the first to explore the consequences on the public information environment of this change in financial market structure. Given the significance of bank consolidation in the U.S. over the last three decades, our results help shed light on the over-time increases in voluntary disclosure by the U.S. public companies (Bushee, et al. (2004)). Because the availability of public information affects the ability of stock markets to allocate resources efficiently, our findings also improve our understanding of the channels through which financial markets affect resource allocation in the economy, and inform the debate on bank- versus market-based financial markets (Levine (2005)). Finally, given the significant differences in banking market structures across

countries, our results also shed light on the reasons for cross-country differences in firms' information environment (Bushman, et al. (2004)).

The rest of the paper is organized as follows. Section 2 discusses related literature and develops our hypotheses. Section 3 describes the data and sample. Main results are presented and discussed in Section 4. Section 5 presents additional analyses and robustness tests and Section 6 concludes.

\section{Related literature and hypotheses development}

\subsection{Prior work on institutional factors and information environment}

Our paper belongs to the literature on how macro-level institutional factors affect firms' information environment. This literature has documented empirical correlations between country level institutional factors (such as a country's legal regime, investor rights protection, and political institutions) and the properties of firms' mandatory disclosure, as measured by the strength of association between accounting earnings and stock returns (Joos and Lang (1994), Ali and Hwang 
(2000)), the timeliness of accounting earnings (Ball et al. (2000)), the extent of earnings management (Leuz et al. (2003)), and the comprehensiveness of disclosure coverage (Bushman et al. (2004)).

Within this literature, our paper relates closely to prior studies on how a country's financial market structure, i.e., whether it is bank- or market-based, affects the demand for public disclosure. The idea is that banks have access to private information about borrowers and therefore countries with more bank-based financial markets have more demand for conservative accounting and less demand for public disclosure. The empirical evidence for the idea is relatively scarce, and the results are mixed. For example, Francis et al. (2005) find no significant relation between the degree of bank market development and firms' voluntary disclosure as measured by the ratings of disclosure quality from the Center for International Financial Analysis (CIFAR). On the other hand, Burghstahler et al. (2006) find that publicly-traded firms are less likely to manage earnings than privately-held firms in countries with more market-based financial markets. Similarly, Ball and Shivakumar (2005) find that among U.K. firms, the speed of loss recognition timeliness is faster for publicly-held firms than for privately-held firms, consistent with the idea that firms relying on different capital sources have different demand for public accounting information.

Recent research has also provided evidence on how market developments such as entry of foreign banks and trading in credit default swaps affects timely recognition of losses in borrowers' accounting reports. Gormley, et al. (2012) find an increase in timely loss recognition after foreign bank entry in India due to greater demand for hard, public information by these banks for screening and monitoring borrowers. Martin and Roychowdhury (2015) find evidence of decrease in timely loss recognition after the initiation of trading in credit default swaps, consistent with a reduction in lenders’ monitoring incentives following this development.

Finally, our paper is also closely related to two recent works on the effects of banking relations on borrowers' voluntary disclosure using micro-level data. Specifically, Lo (2014) finds that borrowers increase disclosure following deterioration in their banks' financial health, consistent 
with the hypothesis that firms increase disclosure to facilitate access to public financing when continued access to bank financing is under threat. Vashishtha (2014) finds that borrowers reduce disclosure after covenant violations; he concludes that reduced disclosure reflects a delegation of monitoring to banks by shareholders who consequently demand less disclosure. Our paper shares with these papers the common theme that borrowers optimally change disclosure in response to changes in the financing and monitoring benefits from banking relationships.

\subsection{Hypothesis development}

Prior work argues that the consolidation in banking industry has significantly altered the scope and nature of banks' operations, their market power, and their ability to finance and monitor borrowers (Berger et al. (1999)). We argue that these changes affect borrowers' disclosure incentives by changing the costs and benefits of banking relationships to borrowers. In this subsection we summarize these arguments.

\subsubsection{Arguments for disclosure increase}

Prior work suggests that bank mergers can cause borrowers to increase disclosure by affecting the nature of bank monitoring and financing. On the monitoring side, the disclosure increase could occur because of changes in the nature of monitoring from being primarily based on soft information to more based on hard, quantitative information. The traditional literature on relationship banking recognizes banks' role as delegated monitors because of their unique ability to access and produce soft, private information about their borrowers (e.g., Diamond (1984, 1991); Fama (1985); James (1987)). Because dispersed public capital providers mainly rely on hard, public information for monitoring, they find it too costly to monitor and provide capital to firms for which much of the information is soft in nature. As a result, for such borrowers, public capital providers optimally delegate (at least part of) the monitoring effort to banks; this reduces public capital providers own demand for public disclosure for monitoring purposes (Ball et al. (2000); Vashishtha (2014)). 
More recent work argues that banking consolidation could fundamentally change the nature of bank monitoring by altering their organizational structures (e.g., Stein (2002); Berger et al. (2005)). Specifically, mergers result in larger, more complex, and hierarchical banking organizations that are less effective at collecting and processing soft information, but may be more efficient at processing hard information. Theoretical studies show that complex, hierarchical organizations rely less (more) on soft (hard) information because such organizations face higher costs in motivating agents to produce and truthfully represent soft information, as well as in accurately communicating soft information within organizations. ${ }^{3}$ Several empirical studies provide evidence that banks' organizational structure indeed affects their relative reliance on soft vs. hard information, and consequently their lending practices. ${ }^{4}$

The shift in the nature of bank monitoring could prompt external capital providers to demand more public disclosure. To the extent banks' comparative advantage in monitoring primarily emanates from their ability to process soft information, following M\&As, public capital providers may no longer find it optimal to delegate the monitoring role to banks and may demand additional public disclosure to facilitate their own monitoring efforts. Moreover, to the extent much of the hard information can be efficiently collected through public disclosures, following M\&As, even banks may reduce their costly private information collection efforts and may instead rely more public

\footnotetext{
${ }^{3}$ For example, Aghion and Tirole (1997), Baker, Gibbons, and Murphy (1999), and Stein (2002) analyze the incentive effect of organizational hierarchy in motivating information production, Crawford and Sobel (1982) highlight the difficulty of truthfully representing information with misaligned incentives, and Radner (1993) and Bolton and Dewatripont (1994) emphasize the costs of transmitting information in large organizations.

${ }^{4}$ For example, consistent with large banks being less able to collect and act on soft information than small banks, Berger et al. (2005) find that large banks are less willing to lend to informationally difficult clients, interact more impersonally with their borrowers, and have shorter and less exclusive relationships. Similarly, Cole, Goldberg, and White (2004) find that large banks are more likely to employ standard criteria obtained from financial statements in loan decisions whereas smaller banks tend to rely on information about the character of the borrowers. Liberti and Mian (2009) find that loan decisions are more likely to be based on hard (soft) information when they are made by managers at higher (lower) levels of the hierarchy. Mian (2006) finds that foreign banks are unable to compete with local banks and resolve local firms' financial constraints, consistent with greater organizational hierarchy (by cultural and geographical distance between headquarters and local branches) reducing banks' incentive and ability to lend to informationally difficult yet fundamentally sound firms.
} 
disclosures. Consistent with this possibility, Gormley et al. (2012) find that foreign banks demand more conservative accounting reports to facilitate their screening and monitoring efforts.

On the financing side, the disclosure increase could be caused by an increase in banks' market power following mergers, which banks could use to limit the supply and/or increase the price of bank credit. Mergers can increase banks' bargaining power vis-à-vis borrowers either by consolidating the supply of bank credit, especially in markets where merged banks have large overlap, or by enabling banks to be more selective in lending as merged banks gain access to alternative markets/clientele and have more business opportunities to pursue. ${ }^{5}$ Banks' increased market power may prompt borrowers to increase disclosure to improve access to alternative public financing. Unlike with banks, public disclosure is a more effective way to resolve information asymmetries and improve terms of financing with public capital providers (Diamond and Verrecchia (1991), Baiman and Verrecchia (1996)). ${ }^{6}$

Anecdotal evidence suggests that banks indeed experience such an increase in market power (Sapsford and Sherer (2001) and Sapsford (2004)). In a 2004 survey, nearly two-thirds of the surveyed chief executive officers and treasurers of companies with revenues of $\$ 1$ billion or more said a bank had denied credit or increased loan prices because the corporate executive did not buy additional services (Sapsford (2004)). The executives in the survey attribute this to the "growing clout and competition in the banking industry that have come with the consolidation and the repeal of laws separating the banking and brokerage business.” In their article in Wall Street Journal, Sapsford and Sherer (2001) also note how borrowers cope with the effects of mergers: "borrowers are coping by borrowing less, raising more in bonds, or giving banks more non-loan business in return for loans.”

\footnotetext{
${ }^{5}$ For example, mergers may allow banks to pursue (presumably higher margin) non-lending activities, at the expense of positive NPV lending activities. Such changes would increase the bargaining power of banks vis-àvis some borrowers.

${ }^{6}$ This is consistent with prior findings of positive relation between firm disclosures and access to external financing (e.g., Frankel, et al. (1995), Lang and Lundholm (2000), Shroff, et al. (2013)).
} 
Academic evidence on the issue is, however, mixed and inconclusive. For example, Berger and Udell (1996) and Erel (2011) find lower post-merger loan rates for small and medium businesses in the U.S.. Black and Strahan (2002) find that the formation of new businesses increases as the share of small banks decrease, consistent with the idea that banking consolidation improves financing to new businesses. At the same time, Garmaise and Moskowitz (2006) find evidence of decreased credit availability and higher rates in areas with significant bank mergers, and Erel (2011) find higher post-merger loan prices when merged banks have significant overlap in their markets. Park and Pennacchi (2009) find lower deposit rates in markets with large banks, suggesting that market power leads to rent extraction from depositors. ${ }^{7}$

\subsubsection{Arguments for decreased or unchanged disclosure}

Prior research also offers arguments that suggest that mergers could lead to no change or even decrease in disclosure. Literature on market for corporate control argues that mergers can act as a disciplining device for firms plagued by agency problems (e.g., Shleifer and Vishny (1997)). As a result, there may be an increase in monitoring effort following mergers at banks that were not sufficiently monitoring their borrowers prior to the mergers. This, in turn, may increase the willingness of public capital providers to delegate the monitoring role to banks, reducing the public capital providers' demand for public disclosure. Even on the financing side, bank mergers could increase the appeal of bank financing relative to public financing if mergers allow banks to generate efficiency gains through economies of scale, scope or both and banks pass on some of these gains to

${ }^{7}$ Outside of U.S., Sapienza (2002) and Bonaccorsi di Patti and Gobbi (2007) find bank mergers in Italy result in termination of bank relationships, especially with informationally opaque firms, reducing these firms' credit availability and investment rates. Karceski et al. (2005) find a significant stock price decline for a sample of Norwegian firms upon their banks' merger announcements. 
borrowers. ${ }^{8}$ In this scenario, borrowers may increase their reliance on bank financing, leading to no change or even decrease in public disclosure.

In summary, mergers can affect borrowers’ disclosure via multiple, non-mutually exclusive channels. While the monitoring style and the market power stories predict an increase in borrower disclosure after bank mergers, the disciplinary role and the efficiency gain stories predict no change, or even a decrease in disclosure. Since the prior literature has not provided clear evidence on the overall effect of mergers on borrowers, little is known about whether and by how much any effect can be attributed to monitoring, market power, or efficiency gains. Therefore, whether mergers can have a meaningful effect on borrowers’ disclosure is ultimately an empirical question.

\section{Sample construction and description}

\subsection{Sample construction}

We draw data from multiple sources to construct our main sample which spans from 1999 to 2008. The sample period is determined primarily by the availability of data on conference calls. Our sample for earnings forecasts (used in additional tests) spans from 1995 to 2008. To construct our base sample, we start with firms in Compustat database for which data on bank loans is available in the Loan Pricing Corporation's (LPC) Dealscan database. We then identify the lead banks for all loan contracts for these firms using the lender information provided in the Dealscan database. Following prior literature, we identify a bank as the lead bank if the Dealscan database indicates it as the lead arranger. When the lead arranger credit is missing, we identify the lead arranger as the lender whose role has been specified as Admin Agent, Agent, Arranger or Lead Bank in the database.

Dealscan typically reports as lead arranger the name of the institution listed on the cover page of a loan document. This often results in regional branches or offices being listed as the lender of record. Because these distinctions are often legal rather than operational, we aggregate these entities

${ }^{8}$ For example, mergers may allow banks to achieve better risk diversification and loan portfolio optimization (Berger et al. (1999)). DeYoung et al. (2009) find significant post-merger performance improvement for banks. 
into their parent institutions using the Federal Financial Institutions Examination Council's National Information Center (NIC) and annual reports as a source of ownership information when necessary.

We collect information on the merger activities of lead banks using the SNL Financial Bank Mergers and Acquisitions Database (SNL database). SNL Financial is a private data vendor that provides comprehensive information on the M\&A activities of banking institutions in the U.S.. We hand-match the lead banks identified from loan contracts to the SNL database using bank names and geographic information, whenever available. We verify the accuracy of the match between the Dealscan loan data and the SNL merger data using information from NIC and press articles available on the internet. The match results in a total of 892 mergers, staggered over 1995-2008. Table 1, Panel A provides the time-series distribution of merger occurrences and the percentage of loan contracts affected by mergers. As expected, as the industry consolidates, the number of mergers gradually declines over time. However, the percentage of loan contracts affected by mergers stays relatively stable at around 50\%, suggesting that approximately half of the observations in our sample are affected by mergers. The staggered distribution enables us to apply the DID design to identify the effect of mergers.

\subsection{Measuring disclosure}

Our main measure of disclosure is based on the incidence of management conference calls. Conference calls are a flexible and rich disclosure medium that allow for the release of a wide variety of information through not only quantitative but also through several qualitative and contextual disclosures. Prior research shows that conference calls convey material information to outsiders (e.g., Frankel et al. (1999), Bowen et al. (2002)), are persistent/recurring once initiated (Skinner (2003)), and can help reduce pricing inefficiency (Kimbrough (2005)). In addition, the open nature of conference calls allows sophisticated analysts/investors to directly communicate with and scrutinize managers (Mayew (2008), Mayew et al. (2013)), making it difficult for managers to hide bad news 
(Hollander et al. (2010)). Collectively, these findings suggest that the use of conference calls reflects a significant commitment by firms to create a transparent information environment.

The data available to us on conference calls is from BestCalls.com and spans years 1999 to 2008. We measure conference call activity using a dummy variable (CONF_CALL) for the issuance of at least one conference call during a quarter. Since prior studies find no known issues with the coverage of BestCalls.com, we code CONF_CALL as zero for firms that never appear in the BestCalls.com database. Our inferences, however, remain unchanged if we remove firms that never appear in the BestCalls.com database. We also note that such data coverage issues are unlikely to affect our findings because we do not expect changes in data coverage of borrowers to systematically coincide with bank mergers. The mean value for CONF_CALL is 0.589 (see Table 1, Panel B).

Our final sample comprises a maximum of 12,955 contracts from 121 lead banks corresponding to 3,611 borrowers for which all required information is available for our main estimation equations. We collect data on required variables at a quarterly frequency over the contract duration for each contract-bank combination. Our unit of analysis is at contract-bank-quarter level. Our sample contains a maximum of 118,269 contract-bank-quarter observations for analyses. The average (median) contract term in our sample is 17 (19) quarters. Table 1, Panel B presents the summary statistics for the main variables used in the analyses. ${ }^{9}$ It shows that bank loans are an important source of financing for our sample firms: on average, borrowers in our sample finance more than a quarter of their assets with bank loans. Furthermore, consistent with prior work on multiple relationships (Detragiache, et al. (2000); Ongena and Smith (2000)), we find that majority of our sample firms rely on a relationship with just one lead bank. Specifically, the median firm $\left(75^{\text {th }}\right.$ percentile) in our sample has 1 (2) relationship. ${ }^{10}$ Given that close to $50 \%$ of our observations are affected by mergers, these statistics suggest that bank mergers can affect an economically large

\footnotetext{
${ }^{9}$ All variable definitions and calculations are described in the Appendix.

${ }^{10}$ Detragiache, et al. (2000) develop a theory for number of relationships and argue that economic conditions in the U.S. favor single relationships..
} 
portion of borrowers' external financing and a large fraction of these borrowers may not be able to easily offset the effects of merger shocks by relying on other banking relationships. ${ }^{11}$

\subsection{Empirical specification}

We estimate the effects of mergers on borrowers' disclosure using the following specification:

$$
\text { CONF_CALL } L_{i, b, t}=\alpha_{i, b}+\gamma_{t}+\beta_{0} M E R G E R_{i, b, t}+\lambda Z_{i, t}+\varepsilon_{i, b, t}
$$

where $C O N F_{-} C A L L_{i, b, t}$ equals 1 if firm i conducts at least one conference call in quarter t during the period it has an on-going syndicated loan contract with bank b. $M E R G E R_{i, b, t}$ is a dummy variable that equals 1 for all quarters subsequent to the completion of the merger in which bank b is involved, and 0 otherwise. $M E R G E R_{i, b, t}$ is set to zero for the entire duration of the loan contract if bank b is not involved in any merger during that period. We drop the transition quarters between the announcement and the completion dates of the mergers. The mean (median) duration of the transition period is 1.76 (1.67) quarters. In untabulated analyses, we find that our inferences remain unchanged if we retain the transition period and set the $M E R G E R_{i, b, t}$ dummy for the transition period to be 1 or 0. $Z_{i, t}$ is a set of firm-quarter control variables commonly used in the literature to explain firms' voluntary disclosures. All control variables are described in the Appendix. Eqn. (1) also includes quarterly time dummies $\left(\gamma_{t}\right)$ and contract-bank fixed effects $\left(\alpha_{i, b}\right)$ to remove the effect of any timespecific common shocks and any unobservable time-invariant cross-sectional differences across borrower-bank combinations.

Eqn. (1) represents a linear probability model for CONF_CALL. We use the linear model as our main specification because prior research shows that non-linear logit or probit models with fixed

${ }^{11}$ Even when there are multiple relationship lenders, it is not clear whether other lenders would be willing to substitute for the loss of financing from the lender affected by merger. For example, as noted in Detragiache, et al. (2000), this could be the case if multiple relationships partly result from banks' desire to share the idiosyncratic credit risk of borrowers. Indeed, Bonaccorsi Di Patti and Gobbi (2007) find that banks mergers have an adverse effect on credit availability for a sample of firms in Italy, where (unlike U.S.) borrowers tend to have a large number of concurrent banking relationships. 
effects can produce biased coefficient estimates due to the incidental parameters problem (Neyman and Scott (1948), Lancaster (2000), Greene (2004)). ${ }^{12}$ Linear models may, however, introduce heteroscedastic and non-normal errors. To address these issues, we use standard errors that are robust to deviations from the assumption of homoscedastic and normal distribution of errors (Wooldridge, 2002, page 454). Linear models may also produce predicted probabilities that fall outside the unit interval. We do not see this as a significant drawback as our main purpose is to estimate the average marginal effects, which, as explained in Angrist and Pischke (2009) and Wooldridge (2002), can be estimated quite well using linear probability models. In robustness check (shown and discussed in Table 2), we find that our inferences remain unchanged if we use a non-linear logit model with contract-bank fixed effects.

With the inclusion of time- and contract-bank-fixed effects, Eqn. (1) represents a differencein-differences specification similar to the one in Bertrand and Mullainathan (2003). This specification can be illustrated with the following example. Suppose that we wish to estimate the effect of the merger between BB\&T and One Valley Bancorp in 2000 on their borrowers' disclosure. We would subtract conference call frequency before 2000 from conference call frequency after 2000 for their borrowers. However, other things in 2000, such as regulatory changes, may have affected these borrowers' disclosure. Choosing a control group, for example, borrowers of Bank One Corp which did not go through mergers in 2000, would help control for regulatory changes. If Bank One’s borrowers were subject to the same regulatory changes, the change in their disclosure would measure the regulation's effect. Eqn. (1) essentially compares the difference in disclosure of borrowers of BB\&T and One Valley Bancorp before and after 2000 (the first difference) to the difference in disclosure of Bank One's borrowers before and after 2000 (the second difference). The difference of

\footnotetext{
${ }^{12}$ See Adams and Ferreira (2008), Benmelech and Frydman (2015), and Hartzmark (2015) for examples that use linear probability models because of this issue.
} 
these two differences provides an estimate of the merger's effect on the disclosure of BB\&T and One Valley Bancorp’s borrowers.

As Bertrand and Mullainathan (2003) note, the difference between the example and the regression framework is that the regression accounts for the fact that there are many mergers staggered over time. The staggered completion of mergers means that the control group includes not only contract relationships that never experience mergers, but also contract relationships that did not experience merger at time t, even if mergers may have taken place for these banks before or after time t. Under the assumption that the timing of bank mergers is exogenous with respect to individual borrowers' disclosure decision, the coefficient on MERGER represents the average causal effect of bank mergers on their borrowers' disclosure. ${ }^{13}$

Because our unit of analysis is at contract-bank-quarter level, firms with multiple syndicated loan contracts and firms with multiple lead banks on a single contract will appear multiple times in our sample for a given quarter. ${ }^{14}$ We therefore obtain all standard errors after clustering at firm-level; this approach allows for arbitrary forms of correlation between observations from the same firm. About 30 percent of observations in our sample are from contracts where the lending banks did not experience mergers during the contract periods. For these observations, the MERGER dummy is not estimable because of the inclusion of the contract-bank fixed effects. These observations serve as the control group to help obtain sharper coefficient estimates. Our results are not affected by excluding these observations.

${ }^{13}$ It is possible that bank mergers may have some market wide effects that are not limited only to the borrowers of banks affected by mergers. By design, Eqn. (1) does not allow us to estimate such market wide effects as the coefficient on MERGER only picks up the effect net of the overall market effects. We choose this specification because our main objective is to examine the causal effect of bank mergers on their borrowers, and because this design has the advantage of better removing the confounding effect of any contemporaneous shocks coinciding with bank mergers and better establishing causality, a point we will return to later in our analyses. While documenting the total market wide effects of bank mergers is an interesting topic on its own, it is beyond the scope of this study.

${ }^{14}$ Because our measure of disclosure is firm-specific, the effect of bank mergers will be underestimated when firms have contemporaneous contracts where lenders of some contracts completed mergers and acquisitions while lenders of other contracts did not go through M\&A. 


\section{Main results}

\subsection{Main effect of bank mergers on borrower disclosure}

Table 2 shows the main results for the effect of bank mergers on borrowers' disclosure. Column (1) presents the results from regressing CONF_CALL on only contract- and quarter- fixedeffects and no control variables. The estimated coefficient for MERGER ( $\beta$ ) is 0.024 , statistically significant at less than $1 \%$ level. Relative to the pre-merger average value of CONF_CALL (at 0.63), the estimate represents about $4 \%$ increase in CONF_CALL frequency. As we discuss later, the effects are larger for borrowers that are most likely to be affected by bank mergers. The explanatory power of the regression is reasonably high: with just the fixed effects, the adjusted R-squared is 0.73. The coefficient for MERGER dummy remains statistically significant in Column (2), which includes time-varying firm-specific control variables. Most importantly, the inclusion of time-varying controls causes little change in the economic magnitude of the coefficient, indicating that bank mergers do not systematically coincide with changes in firm characteristics. This lends support to the argument that bank mergers are likely to be exogenous with respect to firm characteristics that determine disclosure choices.

To further assess causality, we augment Eqn. (1) with an indicator variable for the two quarters prior to the merger announcements (PreMERGER). If mergers cause higher disclosure, we should observe a positive coefficient only for the MERGER variable but not for the PreMERGER variable. Column (3) shows that this is indeed the case: the coefficient estimate for PreMERGER is economically small and statistically indistinguishable from zero. In robustness checks (not shown), we find similar results when we replace PreMERGER with the indicator variable for the periods prior to the two quarters before the merger announcements. In Table 6 (to be discussed later), we find that the effects of mergers are not temporary and persist throughout the post-merger periods.

We next examine whether changes in borrowers' disclosure depend on whether their lending banks were the acquiring banks or the target banks in the M\&As. In Column (4) we split the 
MERGER dummy into two indicator variables, one for mergers of acquiring banks (ACQUIRER) and one for target banks (TARGET). The results show that borrowers in both subgroups increase their disclosure after mergers significantly, with the effects more pronounced for target banks' borrowers. Specifically, the coefficient estimate is 0.017 (t-statistics=2.13) for borrowers of acquirer banks and 0.035 (t-statistics=2.28) for borrowers of target banks. The stronger disclosure response from borrowers of target banks is consistent with the explanation that mergers affect target banks' borrowers more so than acquirer banks', possibly due to more significant changes in target banks' lending operations from their integration into the larger acquirer banks. We explore this line of analysis in greater details later in Table 5 by further identifying borrowers that are more likely to be affected by mergers.

In Column (5), we examine the robustness of our findings to the estimation of a conditional logit model with contract-level and time fixed-effects. Because average marginal effects are not estimable from fixed effect logit models, to facilitate the economic interpretation, we present estimates of odds ratios for all covariates. ${ }^{15}$ Estimates in Column (5) show that the incidence of merger increases the odds of a conference call by about $61 \%$ (t-statistics=3.912). This result suggests that our inferences are unlikely to be driven by unmodelled non-linearities.

\subsection{Can local economic conditions explain the findings?}

In this section, we examine whether changes in local economic conditions associated with bank mergers can explain our main findings. Prior work shows that banking deregulation, which removed regulatory hurdles to bank mergers, triggered significant local economic growth (e.g., Jayaratne and Strahan (1996)), entrepreneurship (Black and Strahan (2002)), and corporate innovation (Chava et al. (2013) and Amore et al. (2013)). These changes in local economic conditions can affect borrowers' incentives for disclosure. To the extent the firm-specific control

\footnotetext{
${ }^{15}$ See Wooldridge (2002, page 492) for a discussion of this point.
} 
variables do not fully absorb the effect of these changes, the coefficient of MERGER can reflect the effect of local conditions.

We perform three analyses to mitigate this concern. First, we directly control for several state-level measures of local economic conditions. These control variables include (i) per capita GDP growth rate, (ii) personal income growth rate, (iii) asset-weighted market-to-book ratio, (iv) total sales growth, (v) total capital expenditure growth, (vi) total R\&D growth, and (vii) the total number of patents granted to companies headquartered in the state. Growth rate for sales, capital expenditure, and $\mathrm{R} \& \mathrm{D}$ is computed by summing these variables for all public firms headquartered in a state. We include these measures for each of the three years centered on the fiscal year of the quarter for which disclosure is measured. We expect these variables to absorb the confounding effect of any past or anticipated changes in local economic conditions that may take place in the same periods as bank mergers. Table 3, Column (1) presents the results of this analysis. Estimates show that adding these controls have little effect on our main inference. The coefficient estimate for MERGER remains significant, and increases slightly from 0.025 (Table 2, Column 2) to $0.027 .^{16}$

In the second analysis, we alter our DID design such that the control group of observations is obtained from the same geographic location and year as the treatment observations. In this analysis, the coefficient on the merger dummy reflects changes in the disclosure of borrowers whose banks are involved in M\&As to contemporaneous changes in the disclosure of borrowers (located in the same geographic location and year as the treatment firms) whose banks are not involved in M\&As. Because the treatment and control firms in this design face similar local conditions, the estimates are unlikely to be confounded by improvements in local growth prospects.

To see this, consider the following example. Firm $A$ is the treatment firm located in state $S$ whose bank went through a merger in period t. Firm $B$ is a control firm located in the same state $S$

\footnotetext{
${ }^{16}$ In untabulated analyses, we also cluster standard errors at the state-level and our inferences remain unchanged.
} 
and firm $C$ is a control firm located in a different state $S$ '. If firm B is not in the sample, the effect of merger is estimated as $\triangle D I S C L O S U R E_{A, t+1}-\triangle D I S C L O S U R E_{C, t+1}$ where $\triangle D I S C L O S U R E_{j, t+1}$ denotes the changes in firm j's disclosure from $t$ to $t+1$. If changes specific to state $S$ drive A's disclosure change and the merger of A's bank, the MERGER dummy could over-estimate the causal effect of bank merger. The over-estimation would be reduced if firm B is also present in the control sample, and would be eliminated if firm B is the only control group under the assumption that changes in local conditions affect A and B similarly.

We implement this design by including location-year interactive dummies in the regressions with the location measured either by state or by the Metropolitan Statistical Areas as defined by the Bureau of Census (MSA). ${ }^{17}$ In this specification, the identification comes only from within state-year or MSA-year variation and the effective control group is borrowers of non-merged banks in the same state or MSA and year as the treatment borrowers. In the example above, when state-time dummies (there will be four of them for two states and periods $t$ and $t+1$ ) are included, the two observations from $\mathrm{C}$ are subsumed by the two state $\mathrm{S}$ '-time interactive dummies and therefore do not contribute to the estimated effect of bank merger. The coefficient on MERGER in this specification is estimated as $\triangle D I S C L O S U R E_{A, t+1}-\triangle D I S C L O S U R E_{B, t+1}$.

We note that this specification is conservative as MERGER is estimated only from the subsample of treatment observations with at least one control observation in the same location-year. The estimates in Columns (2) and (3) of Table 3 show that the effects of MERGER remain economically and statistically significant. Relative to the estimate in the baseline specification (0.025), the coefficients for MERGER are 0.024 (t-stat = 3.07) and 0.029 (t-stat =3.74) when stateyear and MSA-year interactive dummies are included, respectively.

\footnotetext{
${ }^{17}$ See Jayaratne and Strahan (1996) for a similar approach in which they include Region-Year interactive dummies to remove the confounding effects of region specific economic conditions.
} 
The above approach implicitly assumes that changes in local economic conditions have an equal effect on both treatment and control firms within the same geographic location. In the final analysis, we address the possibility that local firms are differentially affected by changes in local conditions by estimating Eqn. (1) on a propensity score matched sample. Specifically, we propensityscore match each treatment borrower to a control borrower from the same state (or MSA) based on industry membership (using Fama-French 48 industry classification), size (measured as book value of assets), growth opportunities (measured as market-to-book ratio), and the time period of the contract. To ensure high match quality, we impose the restriction of common support. Because treatment and control firms in this analysis are forced to be economically similar, they are more likely to respond similarly to changes in local conditions (Smith and Todd (2005)). The disadvantage of this approach is reduced sample size due to dropping of unmatched borrowers. Despite the significantly reduced sample size, results in Column (4) and (5) show that the coefficients of MERGER remain economically and statistically significant. Specifically, the coefficient estimate is 0.023 ( $\mathrm{t}$-stat=2.64) when the location is matched by the state and is 0.033 ( $\mathrm{t}$-stat $=3.49$ ) when the location is matched by MSA. We conclude from these additional analyses that our baseline result is robust to the effects of local economic conditions.

\subsection{Are results driven by borrowers of poorly performing banks?}

One of the motivations for mergers is acquisition of poorly performing banks. As a result, it is possible that our results could reflect the effect of poor bank health and not of bank mergers. For example, Lo (2014) finds that borrowers of unhealthy banks increase disclosure to improve access to alternative public financing. ${ }^{18}$ Moreover, to the extent poor bank performance results from poor borrower performance, our results could also be confounded by poor borrower performance.

\footnotetext{
${ }^{18}$ Lo (2014) documents significant increase in disclosure by borrowers whose lending banks were exposed to the emerging markets financial crisis in the late 1990s. We note that our sample period starts from 1999 and has minimum overlap with the crisis period in Lo (2014) (from the second half of 1997 to the first half of 1999). Our inferences remain unchanged if we estimate our main specification after dropping all observations during the crisis period (results not shown).
} 
Although prior research suggests that merger waves in the U.S. banking industry have largely been driven by regulatory, technological, and competitive changes and most of the mergers involved healthy financial institutions (Pilloff (2004); Adams(2012)), it is possible that some mergers in our sample were disciplinary in nature and involved poorly performing banks (especially the target banks). To the extent declining bank performance coincides with the timing of mergers, the MERGER dummy may be picking up the effect of bank health.

To examine this possibility, we first condition the effect of the MERGER dummy on three measures of bank performance: annual stock return, return on assets, and the percentage of nonperforming loans, all measured over the year prior to mergers. For each performance measure, we create an indicator variable that equals 1 if the measure falls above the sample median value. The bank health explanation predicts that the effect of mergers would be more pronounced for borrowers whose banks performed poorly prior to the mergers. Table 4, Panel A presents the results of this analysis. Inconsistent with the bank health explanation, the estimates in Columns (1) and (2) indicate that the effect of merger on borrowers' disclosure does not differ significantly by bank performance as measured by stock return or return on assets. The estimates in Column (3) suggest that the disclosure actually increases more for borrowers of banks with fewer non-performing loans, with the difference marginally significant at $10 \%$ level.

Because poor bank health could be the result of poor borrower health, we further test this alternative explanation by examining whether our results are driven by poorly performing borrowers. We use three measures of borrowers’ pre-merger performance for this analysis: (i) stock return, (ii) ROA, and (iii) an indicator variable for the presence of investment grade rating. Table 4, Panel B presents the results of this analysis. Estimates in Columns (1) to (3) show that disclosure increase following mergers manifests also for healthy borrowers and is not statistically different from disclosure increase for poorly performing borrowers. In our final analysis to address this issue, we also examine the nature of news disclosed by borrowers. If poor borrower performance is driving our 
results, we would expect disclosure increases to be driven by borrowers with bad news. Using a dummy for negative returns in the current quarter (lagged quarter) as a proxy for bad news, estimates in Column (4) (Column (5)) show that the disclosure increase does not depend on the nature of the news. Collectively, the above results support the interpretation that bank mergers, as opposed to poor bank or borrower health, cause the increase in borrower disclosure.

\section{Additional Analyses}

\subsection{Cross-sectional variations in the effects of bank $M \& A s$}

The analyses thus far provide evidence suggesting that bank mergers cause public information spillover. In this section, we explore the cross-sectional variation in the disclosure increase to shed light on the economic forces underlying the spillover effects. If the disclosure increase reflects borrowers' response to changes in banks' monitoring style and increased market power caused by mergers, then we should observe larger effects for the subsamples of firms that are more likely to be exposed to these effects. We use five partition variables to identify borrowers that are more likely to be affected by these effects of bank mergers.

First, we use two partition variables to identify borrowers that are more likely to be affected by the change in banks' monitoring style following mergers: (i) the number of branches operated by banks prior to mergers and (ii) number of covenants in the loan contracts. We expect banks with fewer pre-merger branches to experience a greater transformation in their monitoring styles because of larger changes in their organizational structure and hierarchy following mergers (Stein (2002)). We therefore predict greater disclosure increase for borrowers of banks with fewer pre-merger branches. ${ }^{19}$ We also predict greater disclosure increase for borrowers whose loan contracts contain more covenants. Because a key role of covenants is to facilitate bank monitoring, the presence of

\footnotetext{
${ }^{19}$ In untabulated sensitivity tests, we find that the effect of number of branches is robust to controlling for bank size (measured as book value of assets). This result is consistent with theoretical works that emphasize the role of organizational hierarchy and not just bank size. DeYoung et al. (1997) find that the number of branches significantly affects banks' lending to informationally difficult smaller businesses, after controlling for bank size and age.
} 
large number of covenants indicates banks' intention to closely monitor the borrowers. As a result, the effects of any changes in banks' monitoring are likely to be larger for borrowers with more covenants.

Next, we use two partition variables to identify borrowers that are more likely to be affected by any adverse financing effects of bank mergers. First, we use an indicator variable for in-state mergers, defined as mergers between banks headquartered in the same state. Compared to out-ofstate mergers, in-state mergers are more likely to adversely affect the supply of bank credit to borrowers, either because in-state mergers increase banks’ market power more (Sapienza (2002), Erel (2011)), or because the merging banks are more likely to reduce their lending in overlapping markets for diversification and risk management considerations. Therefore, we should observe greater disclosure increase for borrowers of banks involved in in-state mergers. Among the borrowerbank relationships that experienced bank mergers, $28.6 \%$ are from mergers between banks headquartered in the same state. Second, we use the remaining time to maturity under the current loan contract. We expect the disclosure increase to be greater for borrowers with shorter remaining time to maturity under the assumption that these borrowers will have larger, and more urgent need to improve access to public financing if bank mergers adversely affect their access to future bank credit.

Finally, we also use the proportion of the borrower's assets financed by the loan contract. Because both monitoring and financing effects of bank mergers are likely to be greater for borrowers with more reliance on bank credit, we expect the disclosure increases to be larger for such borrowers.

We examine the effect of continuous partition variables by creating dummy variables using median cut-offs. Table 5 presents the results of this analysis for each partition variable by showing estimates from modified versions of Eqn. (1) augmented with the partition variable and its interaction term with the bank merger dummy. In each row, the estimates represent the effects of mergers on borrowers in each subgroup, with the differences of the estimates and their statistical significance shown near the bottom of the table. 
As expected, we find evidence of greater disclosure increase for borrowers more likely to be affected by changes in banks' monitoring style. Estimates in Columns (1) and (2) show that mergers have much larger effects on borrowers of banks with fewer pre-merger branches (coefficient=0.071 and t-statistics $=5.85$ ) and borrowers with more covenants in their loan contracts (coefficient=0.047 and t-statistics=3.409). In contrast, the effects of mergers for borrowers of banks with more branches and borrowers with few covenants are statistically and economically insignificant. We also find evidence of greater disclosure increase for borrowers more likely to experience adverse financing effects of bank mergers. The estimates in Column (3) show that while in-state mergers increase the probability of conference call by $9.4 \%$, the estimates for out-of-state mergers are economically and statistically insignificant. Similarly, estimates in Column (4) show that disclosure increases are much larger for borrowers with shorter remaining maturity. Finally, as predicted, we find evidence of greater disclosure increase for borrowers with greater reliance on bank credit. Column (5) shows that the coefficient estimate for the MERGER dummy for borrowers with above median reliance on bank credit is 0.036 (t-statistics $=3.39$ ), compared to a coefficient of 0.013 (t-statistics $=1.51$ ) for borrowers with below median reliance on bank credit.

Also worth noting from the above analysis is that the magnitudes of the effects of bank mergers can be quite large. For example, the increase in conference call frequency of $4.7 \%$ for borrowers with large number of covenants represents an increase of about $8 \%$ over the pre-merger frequency of 59\% for these borrowers. For borrowers of banks involved in in-state mergers, a $9 \%$ increase in conference call frequency represents a 35\% increase over the pre-merger frequency of 27\%. The effects are similarly large for borrowers with high reliance on bank financing, shorter remaining maturity, and borrowers of banks with fewer pre-merger branches.

\subsection{Persistence of the effect of bank M\&As}

In this section we examine whether the disclosure increases following bank mergers are

persistent over time. Several prior studies on disclosure emphasize the importance of the 
commitment to transparency (regardless of the nature of news) for facilitating ongoing monitoring and obtaining capital from public investors (e.g., Diamond and Verrecchia (1991), Baiman and Verrecchia (1996)). In an earlier analysis (Section 4.3) we provide evidence that the disclosure increase is independent of whether the borrower has good or bad news, consistent with the commitment interpretation. The commitment interpretation also implies that the post-merger disclosure increase should not be temporary and should persist over time. We test the persistence of the disclosure increase by replacing the MERGER dummy in our main specification with two separate indicators: NearTerm, which equals 1 for the first four quarters following the merger completion date, and 0 otherwise; and LongTerm, which equals 1 for all quarters following the $4^{\text {th }}$ quarter after the merger completion date, and 0 otherwise ${ }^{20} \mathrm{~A}$ significant coefficient estimate on LongTerm would suggest that the disclosure increase is persistent.

Table 6 presents the estimates for $\mathrm{Z} *$ NearTerm and $Z *$ LongTerm for the subgroups based on the partitioning variables $(\mathrm{Z})$ we examined in Table 5. The estimates show that the disclosure increase is persistent for all subgroups of borrowers that are more affected by the mergers of their lead banks, including firms whose banks engaged in in-state mergers, firms that rely more on bank loans to finance their assets, firms whose loan contracts are closer to maturity, firms whose loan contracts contain more covenants, and firms whose banks operate fewer branches prior to the merger. Collectively, the above findings suggest that the disclosure increase reflects a commitment to increased transparency in response to the changed financing and monitoring environment following bank mergers.

\subsection{Changes in financing patterns}

To further shed light on the economic mechanisms underlying the information spillover effects, in this section we examine whether borrowers exhibit any changes in financing patterns following mergers and whether disclosure increases vary with these changes. As discussed in Section

\footnotetext{
${ }^{20}$ The average (median) number of post-merger quarters is 13 (17).
} 
2, one reason borrowers may increase disclosure is to improve access to alternative public financing because of increase in banks' market power following mergers. This channel, therefore, suggests that borrowers may reduce (increase) reliance on bank debt (public debt) following mergers.

To test this possibility, we examine how borrowers affected by mergers change their financing patterns following the expiration of their current loan contract relative to borrowers that are unaffected by mergers. We use data after the expiration of loan contracts for these tests because that is when we expect changes in reliance on bank credit to be observable. We compare financing arrangements up to four years after the expiration of current loan contracts to financing arrangements up to three years prior to the initiation of the contract. Because on average mergers are announced one year after the initiation of the contract, this approach allows us to compare four years of postmerger financing to (on average) four years of pre-merger financing. ${ }^{21}$

More specifically, we estimate a DID specification similar to Eqn. (1) on a sample of a maximum 118,714 contract-year observations for which the required data is available:

$$
\operatorname{FIN~TERM~}_{i, b, t}=\alpha_{i, b}+\gamma_{t}+\rho_{0} \operatorname{MERGER}_{i, b, t}+\lambda Z_{i, t}+\varepsilon_{i, b, t} \text {, }
$$

where FIN TERM is either equal to the natural logarithm of the total credit available under the most recent loan contract (TOTCREDIT) or the total amount of public debt outstanding (TOTBOND). ${ }^{22,23}$ We gather these data for each borrower at the end of each year in the sample period. We calculate total bond outstanding using the Mergent database, which is a comprehensive source of information on bond issuances. Similar to Eqn. (1), the specification also includes contract-fixed effects $\left(\alpha_{i, b}\right)$, year-fixed effects $\left(\gamma_{t}\right)$, and a vector of time-varying control variables $\left(Z_{i, t}\right)$ that are known to affect

\footnotetext{
${ }^{21}$ Our inferences are robust if we do not include data before the initiation of the contract or use alternative time windows such as one or two years before the initiation of the contract.

${ }^{22}$ We measure total credit using the most recent contract to avoid double counting duplicate contracts because Dealscan records all contracts without distinguishing whether the contract has been renegotiated and replaced. Our inferences, however, are unchanged when we calculate total credit using all outstanding contracts in Dealscan.

${ }^{23}$ To abstract away from economic considerations that drive borrowers' leverage decisions (i.e., relative mix of equity and debt financing) we focus on the potential substitution of bank financing by bond financing. In untabulated analysis, however, we do not find evidence of changes in equity financing following bank mergers.
} 
credit terms. These control variables are described in the caption of Table 7 which presents the results of this analysis. The coefficient of interest is $\rho_{0}$, which estimates the percentage change in financing arrangements of borrowers affected by mergers relative to borrowers unaffected by mergers.

The coefficient estimates on the merger dummy in Columns (1) and (2) of Table 7 show that following mergers, on average borrowers reduce their reliance on bank debt by $8.6 \%$ (tstatistics $=4.885$ ) and increase reliance on public debt by 9.3\% (t-statistics=2.104). The magnitude of the decline in credit availability is economically meaningful and is in line with those documented in Bonnacorsi di Patti and Gobbi (2007). ${ }^{24}$

Bonnacorsi di Patti and Gobbi (2007) also find that mergers interrupt banking relationships and are more likely to result in relationship termination. We also examine this possibility by estimating equation (2) with an indicator for relationship termination (TERMINATION) as the dependent variable. We consider a borrower to have experienced a relationship termination in year $\mathrm{t}$ if its lead arranger at the end of year $\mathrm{t}$ is different from the one in the previous loan contract or if the borrower does not appear in the Dealscan database at the end of year t. Estimates in Table 7, Column (3) show that bank mergers significantly increase the likelihood of relationship termination by $10.3 \%$ $(\mathrm{t}$-statistics $=10.35) .{ }^{25}$

Overall, these findings indicate that following bank mergers, borrowers decrease their reliance on bank debt and increase their reliance on public debt, consistent with the market power story.

\footnotetext{
${ }^{24}$ For example, Table III Column 1 in Bonnacorsi di Patti and Gobbi (2007) shows a 7.9\% decline in credit in year $\mathrm{t}$ for the borrower whose entire bank loan in the previous year was financed by a bank which was a bidder in M\&A in year $\mathrm{t}-1$.

${ }^{25}$ The market power channel offers no clear prediction about the effect on observed equilibrium interest rates on borrowers' loans following bank mergers. This is because borrowers may reject the loan if the rate is too high or choose to borrow smaller amounts in exchange for better rates (and substitute with more bond financing), both of which may endogenously lead to no detectable change in observed interest rates. In untabulated analysis, we find no changes in the average interest rate charged on borrowers' loans following bank mergers.
} 
Next, we examine how disclosure increases following bank mergers covary with these changes in financing patterns using a similar design in Gormley, et al. (2012). Specifically, we construct two indicator variables, one for a decrease in reliance on bank credit and one for an increase in reliance on public debt by comparing the amounts of total credit and total bond outstanding in the pre- and post- merger periods. We then partition the effect of merger dummy using these indicator variables in our disclosure regressions (equation (1)).

Table 8 presents the results of this analysis. Estimates in Column (1) show that although the disclosure increase is larger for borrowers that increase bond financing following mergers (coefficient=0.051 and t-statistics=4.372), it also manifests for borrowers that do not increase bond financing (coefficient $=0.024$ and t-statistics=2.484). When we partition the effect of merger using the indicator variable for credit decrease in Column (2), we find that the disclosure increase manifests both for borrowers that experience a decrease in credit following mergers and those that do not experience a decrease, and the difference is economically and statistically indistinguishable from zero (difference=-0.001 and t-statistics=-0.09). Evidence of disclosure increase for borrowers that do not experience a decline (increase) in bank debt (public debt) suggests that some borrowers increase disclosure purely to meet the changed informational demands triggered by changes in the nature of bank monitoring. At the same time, evidence of greater disclosure increase for borrowers that increase public debt indicates that some borrowers also increase disclosure to improve access to public financing. Overall, these findings suggest that both the monitoring style and the market power channels contribute to bank mergers’ effect on borrowers' disclosure increase.

\subsection{Alternative measures of disclosure}

In our final analyses, we explore the sensitivity of our findings to alternative disclosure measures based on management earnings forecasts, which have been commonly used in prior work to measure managerial propensity to reveal private information. While earnings forecasts are usually released through conference calls and are only one of the several disclosures released in conference 
calls, it is possible that not all firms release earnings forecast information through conference calls. Therefore examining the effect on earnings forecasts also allows us to capture the disclosure activity of firms that do not necessarily rely on conference calls for communicating with public markets. Moreover, prior work suggests that earnings forecasts contain significant amount of information (e.g., Beyer, et al. (2010)) and can facilitate shareholder monitoring (e.g., Armstrong et al. (2014); Vashishtha (2014)) and improve access to public financing (Lo (2014)).

We use two measures of disclosure based on management earnings forecasts. The first measure is a dummy for whether a firm issued at least one forecast during a fiscal quarter (I(Earnings Forecast)). The second measure, Forecast Precision, captures the precision of the forecasts. Following Armstrong et al. (2014), we code Forecast Precision as 4 for point estimates, 3 for range estimates, 2 for open-ended estimates, 1 for qualitative estimates, and 0 for no forecasts. Data on management forecast are obtained from the First Call Company Issued Guidelines database (First Call). We set I(Earnings Forecast) and Forecast Precision as missing for firms that never appear in the first call database. Our sample for this analysis is relatively larger (143,679 observations) because earnings forecast data is available for a larger number of years (1995 to 2009). The mean values for I(Earnings Forecast) and Forecast Precision, as shown in Table 1, Panel B, are 0.396 and 1.227.

Columns (1) and (2) of Table 9 report the results for I(Earnings Forecast) and Forecast Precision, respectively. The estimated coefficients for MERGER are 0.021 and 0.066 , both statistically significant at less than the $5 \%$ level. The explanatory power of the regression is reasonably high with the adjusted R-squared is 0.54 , most of which is contributed to by the fixed effects. Similar to the effects on conference calls (shown in Table 2), the estimates are economically meaningful: relative to the pre-merger average values of I(Earnings Forecast) and Forecast Precision (at 0.375 and 1.166, respectively), the estimates represent about $5.9 \%$ increase in both measures. In untabulated analyses, we replicate the tests in Tables 3-6 using the earnings forecast variables as the dependent variable and find qualitatively similar results. 


\section{Conclusion}

We provide evidence that borrowers increase their disclosure after their lending banks engage in mergers. The evidence is based on a difference-in-differences design in which we compare changes in the disclosure of borrowers whose banks are involved in M\&As to contemporaneous changes in the disclosure of borrowers whose banks are not involved in M\&As. The effects are both economically and statistically significant, especially for borrowers who are more likely to be affected by changes in banks' monitoring styles and market power following mergers. Consistent with the effects of increase in banks' market power, we also document evidence suggesting that borrowers reduce reliance on bank debt and increase reliance on public debt following mergers. We also find that although the disclosure increase is larger for borrowers that increase reliance on public debt, it is not limited to them and even manifests for borrowers that do not experience an increase in public debt or decrease in credit availability. Collectively, our results suggest that banking consolidation prompts borrowers to increase transparency to improve access to public financing and to meet the informational demands of external capital providers in a changed monitoring environment in which both public capital providers and banks rely more on public, hard information for monitoring purposes.

To the best of our knowledge, this study is the first to provide large sample, micro-level evidence on the causal link between bank market structure and borrowing firms' disclosure. Given the significance of banking consolidation in the U.S. over the last three decades and the cross-country differences in bank market structures, our results have implications for understanding both the overtime changes in the amount of voluntary disclosure by U.S. public companies and the cross-country differences in firms' information environment. Because the availability of information affects the ability of stock markets to allocate resources efficiently, our findings also improve our understanding of the channels through which financial markets affect resource allocation in the economy, and inform the debate on bank- versus market-based financial markets. 


\section{References}

Adams, R. B., \& Ferreira, D. 2008. Do directors perform for pay?. Journal of Accounting and Economics, 46(1), 154-171.

Adams, R. M. 2012. Consolidation and merger activity in the United States banking industry from 2000 through 2010. Finance and Economics Discussion Series 2012-51, Federal Reserve Board.

Aghion, P, and J. Tirole. 1997. Formal and real authority in organizations. Journal of Political Economy 105: 1-29.

Allen, F., and D. Gale. 2001. Comparative financial systems: a survey. Wharton School Center for Financial Institutions, University of Pennsylvania.

Ali, A. and L. S. Hwang. 2000. Country-specific factors related to financial reporting and the value relevance of accounting data. Journal of Accounting Research 38: 1-21.

Amel D., C. Barnes, F. Panetta, and C. Salleo. 2004. Consolidation and efficiency in the financial sector: a review of the international evidence. Journal of Banking and Finance 28: 2493-2519.

Amore, M. D., Schneider, C., and Žaldokas, A. 2013. Credit supply and corporate innovation. Journal of Financial Economics 109: 835-855.

Angrist, J.D., and J. Pischke. 2009. Mostly Harmless Econometrics: An Empiricist's Companion. Princeton University Press, Princeton, NJ.

Armstrong, C., J. Core, and W. R. Guay. 2014. Do independent directors cause improvements in firm transparency? Journal of Financial Economics 113(3): 383-403.

Baiman, S. and R. Verrecchia. 1996. The relation among capital markets, financial disclosure, production efficiency, and insider trading. Journal of Accounting Research 34: 1-22.

Baker, G., R. Gibbons, and K.J. Murphy. 1999. Information authority in organizations. Journal of Law, Eonomics, and Organizations 15: 56-73.

Ball, R., S. Kothari, and A. Robin. 2000. The effect of international institutional factors on properties of accounting earnings. Journal of Accounting and Economics 29: 1-51.

Ball, R. and L. Shivakumar. 2005. Earnings quality in UK private firms: comparative loss recognition timeliness. Journal of Accounting and Economics 39: 83-128.

Benmelech, E., \& Frydman, C. (2015). Military CEOs. Journal of Financial Economics 117: 43-59.

Berger, A. N., Demsetz, R. S., and Strahan, P. E. 1999. The consolidation of the financial services industry: Causes, consequences, and implications for the future. Journal of Banking \& Finance 23: 135-194.

Berger, A.N., N. Miller, M. Petersen, R. Rajan, and J. Stein. 2005. Does function follow organizational form? Evidence from the lending practices of large and small banks. Journal of Financial Economics 76: 237-69.

Berger, A.N., and G.F. Udell. 1996. Universal banking and future of small business lending. In A. Saunders and I. Walter (eds), Financial System Design: The Case for Universal Banking. Homewood, IL: Irwin Publishing.

Bertrand, M., and S. Mullainathan. 2003. Enjoying the quiet life? Corporate governance and managerial preference. Journal of Political Economy 111: 1043-1075. 
Beyer, A., D.A. Cohen, T. Z. Lys, and B. R. Walther. 2010. The financial reporting environment: Review of the recent literature. Journal of Accounting and Economics 50: 296-343.

Black, S. E., and Strahan, P. E. 2002. Entrepreneurship and bank credit availability. The Journal of Finance 57: 2807-2833.

Bolton, P., and M. Dewatripont. 1994. The firm as a communication network. Quarterly Journal of Economics 109: 809-840.

Bonaccorsi di Patti, E., and G. Gobbi. 2007. Winners or losers? the effect of banking consolidation on borrowers. Journal of Finance 62: 669-96.

Bowen, R. M., Davis, A. K., and Matsumoto, D. A., 2002. Do conference calls affect analysts' forecasts? Accounting Review, 77: 285-316.

Burghstahler, D., L. Hail, and C. Leuz. 2006. The importance of reporting incentives: earnings management in European private and public firms. Accounting Review 81: 983-1016.

Bushee, B. J., D. A. Matsumoto, and G. S. Miller. 2004. Managerial and investor responses to disclosure regulation: The case of Reg FD and conference calls. Accounting Review 79: 617-643.

Bushman, R.M., J. D. Piotroski, and A. J. Smith. 2004. What determines corporate transparency? Journal of Accounting Research 42: 207-252.

Chava, S., Oettl, A., Subramanian, A., and Subramanian, K. V. 2013. Banking deregulation and innovation. Journal of Financial Economics 109: 759-774.

Cole, R. A., L. G. Goldberg, and L.J. White. 2004. Cookie cutter vs. character: the micro structure of small business lending by large and small banks. Journal of Financial and Quantitative Analysis 39: $227-251$.

Crawford, D., and J. Sobel. 1982. Strategic information transmission. Econometrica 50: 1431-52.

Detragiache, E., Garella, P., and Guiso, L. 2000. Multiple versus single banking relationships: Theory and evidence. Journal of Finance, 1133-1161.

DeYoung, R. D. D. Evanoff, and P. Molyneux. 2009. Mergers and acquisitions of financial institutions: A review of the post-2000 literature. Journal of Financial Service Research 36: 87110.

Diamond, D. W. 1984. Financial intermediation and delegated monitoring. Review of Economic Studies 51: 393-414.

Diamond, D. W. 1991. Monitoring and reputation: the choice between bank loans and directly placed debt. Journal of Political Economy 99: 689-721.

Diamond, D. and R. Verrecchia. 1991. Disclosure, liquidity, and the cost of capital. Journal of Finance 46: 1325-1359.

Erel, I. 2011. The effect of bank mergers on loan prices: evidence from the United States. Review of Financial Studies 24: 1068-1101.

Fama, E. F. 1985. What's different about banks?. Journal of monetary economics 15: 29-39.

Francis, J.R., I. K. Khurana, and R. Pereira. 2005. Disclosure incentives and effects on cost of capital around the world. Accounting Review 80: 1125-1162.

Frankel, R., M. McNichols, and G. P. Wilson. 1995. Discretionary disclosure and external financing. Accounting Review 70: 135-150. 
Frankel, R., M. Johnson, and D. J. Skinner. 1999. An empirical examination of conference calls as a voluntary disclosure medium." Journal of Accounting Research 37: 133-150.

Garmaise, M. J., and T. J. Moskowitz. 2006. Bank mergers and crime: The real and social effects of credit market competition. The Journal of Finance 61: 495-538.

Gormley, T. A., Kim, B. H., and Martin, X. 2012. Do firms adjust their timely loss recognition in response to changes in the Banking Industry?. Journal of Accounting Research 50: 159-196.

Greene, W. 2004. The behavior of the maximum likelihood estimator of limited dependent variable models in the presence of fixed effects. Econometric Journal 7: 98-119.

Hartzmark, S. M. (2015). The worst, the best, ignoring all the rest: The rank effect and trading behavior. Review of Financial Studies 28, 1024-1059.

Hollander, S., M. Pronk, and E. Roelofsen. 2010. Does silence speak? An empirical analysis of disclosure choices during conference calls. Journal of Accounting Research 48: 531-563.

James, C. 1987. Some evidence on the uniqueness of bank loans. Journal of Financial Economics 19: 217-35.

Jayaratne, J., and P. E. Strahan. 1996. The finance-growth nexus: Evidence from bank branch deregulation. The Quarterly Journal of Economics: 639-670.

Joos, P., and M. Lang. 1994. The effects of accounting diversity: evidence from the European Union. Journal of Accounting Research 32(Supplement): 141-68.

Karceski, J., S. Ongena, and D.C. Smith. 2005. The impact of bank consolidation on commercial borrower welfare. Journal of Finance 60: 2043-2082.

Kimbrough, M.D. 2005. The effect of conference calls on analyst and market underreaction to earnings announcements. The Accounting Review 80: 189-219.

Lancaster, T. 2000. The incidental parameter problem since 1948. Journal of econometrics, 95(2), 391-413.

Lang, M. H., and R. J. Lundholm. 2000. Voluntary Disclosure and Equity Offerings: Reducing Information Asymmetry or Hyping the Stock? Contemporary Accounting Research 17: 623-662.

Leuz, C., D. Nanda, and P. D. Wysocki. 2003. Earnings management and investor protection: an international comparison. Journal of Financial Economics 69: 505-27.

Levine, R. 2005. Finance and growth: theory and evidence. Handbook of economic growth 1: 865934.

Liberti, J. M. and A. R. Mian. 2009. Estimating the effect of hierarchies on information use. Review of Financial Studies 22: 4057-4090.

Lo, A. K. 2014. Do declines in bank health affect borrowers' voluntary disclosure? evidence from international propagation of banking shocks. Journal of Accounting Research 52: 541-581.

Martin, X., and Roychowdhury, S. 2015. Do financial market developments influence accounting practices? Credit default swaps and borrowers' reporting conservatism. Journal of Accounting and Economics 59: 80-104.

Mayew, W. J. 2008. Evidence of management discrimination among analysts during earnings conference calls. Journal of Accounting Research 46: 627-659. 
Mayew, W. J., N. Y. Sharp, and M. Venkatachalam. 2013. Using earnings conference calls to identify analysts with superior private information. Review of Accounting Studies 18: 386-413.

Mian, A. R. 2006. Distance constraints: the limits of foreign lending in poor economies. Journal of Finance 61: 1465-1505.

Neyman, J., \& Scott, E. L. 1948. Consistent estimates based on partially consistent observations. Econometrica: Journal of the Econometric Society, 1-32.

Ongena, Steven, and David C. Smith. 2000. "What determines the number of bank relationships? Cross-country evidence." Journal of Financial Intermediation 9.1: 26-56.

Park, K., and G. Pennacchi. 2009. Harming depositors and helping borrowers: the disparate impact of bank consolidation. Review of Financial Studies 22: 1-40.

Pilloff, S. J. 2004. Bank merger activity in the United States. Board of Governors of the Federal Reserve System: staff study 176.

Radner, R. 1993. The organization of decentralized information processing. Econometrica 61: 110946.

Sapienza, P. 2002. The effects of banking mergers on loan contracts. Journal of Finance 57: 329-68.

Sapsford, J. 2004. Executives see rise in "tying" loans to other fees. The Wall Street Journal: A1, June 9, 2004.

Sapsford, J., and P. Sherer. 2001. Fewer banks mean costlier credit lines. The Wall Street Journal: C1, March 14, 2001.

Shleifer, A., and Vishny, R. W. 1997. A survey of corporate governance. Journal of Finance, 52: 737-783.

Shroff, N., Sun, A. X., White, H. D. and Zhang, W. 2013. Voluntary Disclosure and Information Asymmetry: Evidence from the 2005 Securities Offering Reform. Journal of Accounting Research 51: 1299-1345.

Skinner, D. J. 2003. Should firms disclose everything to everybody? A discussion of "Open vs. closed conference calls: the determinants and effects of broadening access to disclosure". Journal of Accounting and Economics 34: 181-187.

Smith, J. A., and Todd, P. E. 2005. Does matching overcome LaLonde's critique of nonexperimental estimators? Journal of econometrics, 125(1), 305-353.

Stein, J. 2002. Information production and capital allocation: Decentralized versus hierarchical firms. Journal of Finance 57: 1891-1922.

Vashishtha, R. 2014. The role of bank monitoring in borrowers' discretionary disclosure: evidence from covenant violations. Journal of Accounting and Economics 57: 176-195.

Wooldridge, J. 2002. Econometric Analysis of Cross Sectional and Panel Data. The MIT Press, Cambridge, MA. 


\section{Table 1: Descriptive Statistics}

Panel A provides the descriptive statistics for the time-series distribution of merger incidences in our sample and their impact on loan contracts in Dealscan, as measured by the percentage of contracts affected by mergers, from 19952008. Panel B provides the summary statistics for the key variables in our primary sample for the analyses on conference calls (results shown in Tables 2-8). The sample period spans from 1999 to 2008 and contains a maximum of 118,269 contract-bank-quarter observations. All variables are defined in the Appendix.

Panel A: Time-series distribution of sample mergers

\begin{tabular}{ccc}
\hline Year & $\begin{array}{c}\text { Number of } \\
\text { mergers }\end{array}$ & $\begin{array}{c}\text { \% of contracts affected by } \\
\text { mergers }\end{array}$ \\
\hline 1995 & 162 & $55 \%$ \\
1996 & 123 & $58 \%$ \\
1997 & 99 & $46 \%$ \\
1998 & 149 & $53 \%$ \\
1999 & 68 & $53 \%$ \\
2000 & 55 & $48 \%$ \\
2001 & 41 & $52 \%$ \\
2002 & 35 & $36 \%$ \\
2003 & 22 & $29 \%$ \\
2004 & 27 & $65 \%$ \\
2005 & 21 & $54 \%$ \\
2006 & 33 & $42 \%$ \\
2007 & 38 & $45 \%$ \\
2008 & 19 & $48 \%$ \\
Total / Average & 892 & $49 \%$ \\
\hline
\end{tabular}


Panel B: Summary statistics

\begin{tabular}{|c|c|c|c|c|c|c|c|}
\hline & Mean & Std & p10 & p25 & p50 & p75 & p90 \\
\hline \multicolumn{8}{|l|}{ Merger Variables } \\
\hline Merger & 0.480 & 0.50 & 0.00 & 0.00 & 0.00 & 1.00 & 1.00 \\
\hline Acquirer & 0.398 & 0.49 & 0.00 & 0.00 & 0.00 & 1.00 & 1.00 \\
\hline Target & 0.112 & 0.32 & 0.00 & 0.00 & 0.00 & 0.00 & 1.00 \\
\hline In-state & 0.195 & 0.40 & 0.00 & 0.00 & 0.00 & 1.00 & 1.00 \\
\hline \multicolumn{8}{|l|}{ Disclosure Variables } \\
\hline Conf_call & 0.589 & 0.49 & 0.00 & 0.00 & 0.00 & 1.00 & 1.00 \\
\hline Forecast & 0.396 & 0.49 & 0.00 & 0.00 & 0.00 & 1.00 & 1.00 \\
\hline Precision & 1.227 & 1.56 & 0.00 & 0.00 & 0.00 & 3.00 & 3.00 \\
\hline \multicolumn{8}{|l|}{ Control Variables } \\
\hline Assets (\$ millions) & 11,512 & 70,982 & 145 & 441 & 1,556 & 5,789 & 19,314 \\
\hline $\mathrm{B} / \mathrm{M}$ & 0.723 & 0.26 & 0.37 & 0.53 & 0.72 & 0.90 & 1.05 \\
\hline Leverage & 0.310 & 0.20 & 0.06 & 0.17 & 0.30 & 0.42 & 0.55 \\
\hline $\mathrm{R} \& \mathrm{D}$ & 0.004 & 0.01 & 0.00 & 0.00 & 0.00 & 0.00 & 0.01 \\
\hline \#Segment & 2.230 & 1.46 & 1.00 & 1.00 & 2.00 & 3.00 & 4.00 \\
\hline Age & 22.253 & 20.1 & 3.5 & 7.2 & 14.6 & 32.7 & 54.0 \\
\hline Volatility & 0.121 & 0.07 & 0.05 & 0.07 & 0.10 & 0.15 & 0.20 \\
\hline Price & 25.937 & 42.05 & 4.59 & 10.06 & 19.25 & 32.30 & 48.79 \\
\hline Return & 0.031 & 0.28 & -0.25 & -0.11 & 0.02 & 0.14 & 0.29 \\
\hline \multicolumn{8}{|l|}{ Loan Contract Variables } \\
\hline \%BankLoan & 0.253 & 0.218 & 0.04 & 0.10 & 0.19 & 0.35 & 0.54 \\
\hline Remaining maturity (days) & 1,284 & 706 & 361 & 778 & 1,247 & 1,715 & 2,185 \\
\hline \# of covenants & 4.306 & 2.626 & 1.00 & 2.00 & 4.00 & 6.00 & 8.00 \\
\hline \# of banking relations & 1.676 & 0.853 & 1.00 & 1.00 & 1.00 & 2.00 & 3.00 \\
\hline Dummy for multiple relations & 0.479 & 0.500 & 0.00 & 0.00 & 0.00 & 1.00 & 1.00 \\
\hline
\end{tabular}




\section{Table 2: Effect of Bank Mergers on Borrower Disclosure}

This table presents regression estimates of Eqn. (1) with the dependent variable of CONF_CALL, an indicator variable for the holding of a conference call by the borrower during a fiscal quarter. MERGER equals 1 for quarters after the completion of the bank merger and zero otherwise. TARGET equals 1 for quarters after the completion of the acquisition of the borrowers' bank by another bank, and zero otherwise. ACQUIRER equals 1 for quarters after the completion of the acquisition by the borrowers' bank, and zero otherwise. PRE_MERGER equals 1 for two quarters prior to the announcement of the bank merger, and zero otherwise. Column (1) - (4) estimate Eqn. (1) with linear regressions, and Column (5) estimates Eqn. (1) with conditional logic model where the coefficient estimates represent odd ratios. All regressions include contract-bank and quarter fixed effects. All control variables are defined in the Appendix. T-statistics, reported in parentheses, are calculated based on robust standard errors obtained by clustering at the firm level. Statistical significance (two-sided) at the $10 \%, 5 \%$ and $1 \%$ level is denoted by $*$, **, and ***, respectively.

\section{$(1)$}

\section{PRE_MERGER}

MERGER

TARGET

ACQUIRER

Log(assets)

$\mathrm{B} / \mathrm{M}$

Leverage

R\&D

\#Segment

$\log ($ age $)$

Volatility

Log(price)

Return

Contract-bank fixed effects included

Quarter fixed effects included

Observations

Adj R-squared

Psuedo R-squared
(2)

(3)

$-0.004$

(0.647)

$0.024 * * * \quad 0.025 * * * \quad 0.022 * *$

(2.985)

(3.143)

(2.422)

$0.035^{* *}$

(2.276)

$0.017 * *$

(2.126)

$0.044 * * *$

(3.715)

(3.755)

$0.045^{* * *}$

(3.763)

$-0.031$

$(-1.243)$

$-0.032$

(-1.209)

$-0.077^{* *}$

$(-1.246)$

$-0.076^{* *}$

$(-2.283)$

$(-2.281)$

$-0.077^{* *}$

$(-2.296)$

$-0.080$

$-0.078$

$(-0.298)$

$(-0.292)$

$-0.066$

$(-0.248)$

0.024 *

0.023*

$0.023^{*}$

(1.684)

(1.682)

(1.677)

0.045

(1.489)

0.045

(1.486)

$-0.446 * * *$

$-0.446^{* * *}$

(-6.925)

$0.028 * * *$

(-6.918)

$0.028 * * *$

(3.545)

(3.545)

-0.012 *

-0.012 *

(-1.921)

(-1.918)

0.045

(1.505)

$-0.444^{* * *}$

(-6.853)

$0.029 * * *$

(3.559)

-0.012 *

(-1.917)

$1.612^{* * *}$

(3.912)

(5)

\section{(3.912)}

$2.015^{* * *}$

(3.501)

0.535**

(-1.974)

$0.208 * * *$

$(-3.112)$

0.077

$(-0.536)$

1.084

(0.293)

1.608

(1.204)

$0.002 * * *$

$(-5.826)$

$1.284^{* * *}$

(2.619)

0.974

$(-0.276)$

$\begin{array}{cccc}\text { Yes } & \text { Yes } & \text { Yes } & \text { Yes } \\ \text { Yes } & \text { Yes } & \text { Yes } & \text { Yes } \\ 118,269 & 118,269 & 118,269 & 117,759 \\ 0.729 & 0.732 & 0.732 & 0.732\end{array}$

Yes

Yes

118,269

0.567 


\section{Table 3: Can local economic shocks explain the results?}

This table presents results from estimation of several modified versions of Equation (1) to address concerns about the confounding effect of local economic conditions. The dependent variable is an indicator for the holding of a conference call by the borrower during a fiscal quarter (CONF_CALL). MERGER equals 1 for quarters after the completion of the bank merger and zero otherwise. Column (1) includes time-varying state-level control variables for the three years centered on the quarter of disclosure including: (i) per capita GDP growth rate, (ii) personal income growth rate, (iii) asset-weighted market-to-book ratio, (iv) total sales growth, (v) total capital expenditure growth, (vi) total R\&D growth, and (vii) and the total number of patents granted to companies headquartered in the state. Growth rate for sales, capital expenditure, and $R \& D$ is computed by summing these variables for all public firms headquartered in a state. Columns (2) and (3) include state-year and MSA-year interactive dummies. Column (4) and Column (5) present results from estimation of Equation (1) on a propensity score matched sample of treatment and control firms from the same state and MSA, respectively. The propensity score matching is based on industry membership (Fama-French 48 industries classification), contract period, asset size, and market-to-book ratio. All regressions include the control variables (coefficient estimates omitted for space constraints), and contract- and calendar quarter-fixed effects. T-statistics, reported in parentheses, are calculated based on robust standard errors obtained by clustering at the firm level. Statistical significance (two-sided) at the $10 \%, 5 \%$, and $1 \%$ level is denoted by *, **, and ***, respectively.

\begin{tabular}{lccccc}
\hline & $(1)$ & $(2)$ & $(3)$ & $(4)$ & $(5)$ \\
\hline & $\begin{array}{c}\text { Time- } \\
\text { varying state } \\
\text { controls }\end{array}$ & $\begin{array}{c}\text { State-year } \\
\text { interactive } \\
\text { dummies }\end{array}$ & $\begin{array}{c}\text { MSA-year } \\
\text { interactive } \\
\text { dummies }\end{array}$ & $\begin{array}{c}\text { State-PS } \\
\text { matched }\end{array}$ & $\begin{array}{c}\text { MSA-PS } \\
\text { matched }\end{array}$ \\
\hline MERGER & $\begin{array}{c}0.027^{* * *} \\
(3.357)\end{array}$ & $\begin{array}{c}0.024^{* * *} \\
(3.066)\end{array}$ & $\begin{array}{c}0.029^{* * *} \\
(3.735)\end{array}$ & $\begin{array}{c}0.023^{* * *} \\
(2.637)\end{array}$ & $\begin{array}{c}0.033^{* * *} \\
(3.488)\end{array}$ \\
$\begin{array}{l}\text { Firm-year control variables } \\
\text { included }\end{array}$ & Yes & Yes & Yes & Yes & Yes \\
$\begin{array}{l}\text { Contract-bank fixed effects } \\
\text { included }\end{array}$ & Yes & Yes & Yes & Yes & Yes \\
$\begin{array}{l}\text { Quarter fixed effects } \\
\text { included }\end{array}$ & Yes & Yes & Yes & Yes & Yes \\
$\begin{array}{l}\text { Observations } \\
\text { Adj. R-squared }\end{array}$ & 115,377 & 116,046 & 115,312 & 92,775 & 80,249 \\
& 0.736 & 0.772 & 0.784 & 0.725 & 0.722 \\
\hline
\end{tabular}




\section{Table 4: Are results driven by acquisitions of poorly performing banks?}

Panel A presents evidence on how borrowers' disclosure response following bank mergers varies by banks' pre-merger financial health. Coefficient estimates are obtained by estimating modified versions of Eqn. (1) augmented with indicator variables and their interaction terms with the MERGER dummy as additional covariates. Column (1) includes the interactive term between Merger and an indicator variable I(High Bank Stock Return) that equals 1 when the merged bank's stock return in the 12-month prior to the merger is above sample median. Column (2) includes the interactive term with an indicator I(High Bank ROA) for whether the merged bank has above sample median value of the percentage of return on assets. Column (3) includes the interactive term with an indicator I(High Bank NPLoan) for whether the merged bank has above sample median value of the percentage of non-performing loans.

Panel B presents evidence on how borrowers' disclosure response following bank mergers varies by borrowers' premerger performance and by the nature of news borrowers may have. Column (1) includes the interactive term between Merger and an indicator variable I(High Borrower Stock Return) that equals 1 when the borrower's stock return in the 12-month prior to the merger is above sample median. Column (2) includes the interactive term with an indicator I(High Borrower ROA) for whether the borrower has above sample median value of the percentage of return on assets. Column (3) includes the interactive term with an indicator I(Borrower Investment Grade) for whether the borrower has an investment grade rating on its debt issuance. Columns (4) and (5) include the interactive terms with an indicator variable for whether the borrower's stock return is negative (I(Borrower BadNews)); In Column (4), the stock return is measured during the same quarter as the dependent variable and in Column (5) the stock return is measured during the prior quarter.

All specifications include firm-specific time-varying control variables, contract-bank and calendar quarter fixedeffects. For brevity, coefficient estimates on control variables are omitted. All control variables are defined in the Appendix. T-statistics, reported in parentheses, are calculated based on robust standard errors obtained by clustering at the firm level. Statistical significance (two-sided) at the $10 \%, 5 \%$, and $1 \%$ level is denoted by $*$, **, and $* * *$, respectively.

Panel A: Effect of bank health

\begin{tabular}{lccc}
\hline & $(1)$ & $(2)$ & $(3)$ \\
\hline MERGER & Bank stock return & Bank ROA & Non-performing loan \\
\hline & $0.026^{* * *}$ & $0.030^{* *}$ & $0.032^{* * *}$ \\
MERGER*I(High Bank Stock Return) & $(2.673)$ & $(2.318)$ & $(3.487)$ \\
MERGER*I(High Bank ROA) & -0.001 & & \\
& $(-0.078)$ & & \\
MERGER*I(High Bank NPLoan) & & -0.004 & \\
& & $(-0.290)$ & $-0.020^{*}$ \\
Control variables included & & & $(-1.801)$ \\
Contract-bank fixed-effects included & & & \\
Quarter fixed-effects included & Yes & Yes & Yes \\
Observations & Yes & Yes & Yes \\
Adj R-squared & & & Yes \\
\hline
\end{tabular}




\section{Table 4 (Cont'd):}

Panel B: Effect of borrower performance

\begin{tabular}{|c|c|c|c|c|c|}
\hline & (1) & (2) & (3) & (4) & (5) \\
\hline & $\begin{array}{l}\text { Stock } \\
\text { return }\end{array}$ & ROA & $\begin{array}{c}\text { Investment } \\
\text { grade } \\
\text { rating } \\
\end{array}$ & $\begin{array}{c}\text { News in } \\
\text { current } \\
\text { quarter }\end{array}$ & $\begin{array}{c}\text { News in } \\
\text { previous } \\
\text { quarter }\end{array}$ \\
\hline MERGER & $\begin{array}{c}0.027 * * \\
(2.372)\end{array}$ & $\begin{array}{c}0.025 * * * \\
(2.225)\end{array}$ & $\begin{array}{c}0.025^{* * *} \\
(2.676)\end{array}$ & $\begin{array}{c}0.025 * * * \\
(3.157)\end{array}$ & $\begin{array}{c}0.022 * * * \\
(2.723)\end{array}$ \\
\hline MERGER*I(High Borrower Stock Return) & $\begin{array}{c}-0.003 \\
(-0.196)\end{array}$ & & & & \\
\hline MERGER*I(High Borrower ROA) & & $\begin{array}{c}0.006 \\
(0.415)\end{array}$ & & & \\
\hline MERGER*I(Borrower InvGrade) & & & $\begin{array}{c}-0.001 \\
(-0.107)\end{array}$ & & \\
\hline MERGER*I(Borrower BadNews) & & & & $\begin{array}{c}-0.000 \\
(-0.110)\end{array}$ & $\begin{array}{c}0.006 \\
(1.368)\end{array}$ \\
\hline Control variables included & Yes & Yes & Yes & Yes & Yes \\
\hline Contract-bank fixed-effects included & Yes & Yes & Yes & Yes & Yes \\
\hline Quarter fixed-effects included & Yes & Yes & Yes & Yes & Yes \\
\hline Observations & 103,877 & 109,064 & 118,269 & 118,269 & 118,269 \\
\hline Adj R-squared & 0.728 & 0.732 & 0.732 & 0.732 & 0.732 \\
\hline
\end{tabular}




\section{Table 5: Cross-Sectional Variations in the Effects of Bank Mergers}

This table presents evidence on how borrowers' disclosure response following bank mergers varies by merger and borrower characteristics. Dependent variable CONF_CALL is an indicator for whether the firm holds a conference call during a fiscal quarter. Coefficient estimates are obtained by estimating an augmented version of Eqn. (1) that includes the partition variable and its interaction with the MERGER dummy as additional covariates. Partition variables examined are: (i) an indicator variable that equals 1 if the merging bank has above median number of branches prior $t$ mergers; (ii) an indicator for whether the number of covenants in the borrower's loan contract is above sample median;

(iii) an indicator for whether the merging banks are headquartered in the same state; (iv) an indicator variable that equals 1 if the remaining maturity on the loan contract is below sample median; and (v) an indicator variable that equals 1 if the aggregate credit available under the loan contract scaled by borrowers' total assets is above sample median. All specifications include contract-bank and quarter fixed-effects. For brevity, coefficient estimates on control variables are omitted. All control variables are defined in the Appendix. T-statistics, reported in parentheses, are calculated based on robust standard errors obtained by clustering at the firm level. Statistical significance (two-sided) at the $10 \%, 5 \%$, and $1 \%$ is denoted by *, **, and ***, respectively.

\begin{tabular}{lc}
\hline $\begin{array}{l}\text { Effects of bank merger on disclosure } \\
\text { by borrowers of }\end{array}$ & (1) \\
\hline & \\
Banks with more branches & -0.004 \\
& $(-0.545)$ \\
Banks with fewer branches & $0.071^{* * *}$ \\
& $(5.852)$
\end{tabular}

Low \# of Covenants

High \# of Covenants

Out-of-state mergers

In-state mergers

Low RemainingMaturity

High RemainingMaturity

Low \%BankLoan

High \%BankLoan

Diff. between the two subgroups

Control variables included

Contract-bank fixed-effects included

Quarter fixed-effects included

(5.852)
(2)

(3)

(4)

(5)
0.011

(1.203)

$0.047 * * *$

(3.409)

$$
\begin{gathered}
0.000 \\
(0.002) \\
0.0943 * * *
\end{gathered}
$$

(4.373)

$0.035^{* * *}$

0.007

0.591

$0.036 * * *$

\begin{tabular}{ccccc}
$0.075^{* * *}$ & $0.036^{* *}$ & $0.094^{* * *}$ & $0.029 * *$ & $0.023^{*}$ \\
$(6.038)$ & $(2.416)$ & $(4.254)$ & $(2.328)$ & $(1.931)$ \\
& & & & \\
Yes & Yes & Yes & Yes & Yes \\
Yes & Yes & Yes & Yes & Yes \\
Yes & Yes & Yes & Yes & Yes \\
& & & & \\
117,505 & 98,303 & 118,269 & 118,269 & 116,798 \\
0.732 & 0.732 & 0.732 & 0.732 & 0.730 \\
\hline
\end{tabular}

Observations

Adj R-squared 


\section{Table 6: Persistence of the Effects of Bank Mergers on Borrower Disclosure}

This table presents evidence on the persistence of the increase in borrowers' disclosure following bank mergers. NearTerm takes value of 1 for the first four quarters after the merger completion date, and 0 otherwise; and LongTerm takes value of 1 for all quarters following the $4^{\text {th }}$ quarter after the merger completion date, and 0 otherwise. The partition variables are defined in Table 5. Coefficient estimates are obtained from an augmented version of Eqn. (1) that includes the partition variables and their interaction terms with NearTerm and LongTerm dummies as additional covariates. All specifications include firm-year specific control variables, and contract-bank and calendar quarter fixed-effects. For brevity, coefficient estimates on control variables are omitted. All control variables are defined in the Appendix. T-statistics, reported in parentheses, are calculated based on robust standard errors obtained by clustering at the firm level. Statistical significance (two-sided) at the $10 \%, 5 \%$, and $1 \%$ level is denoted by $*$, **, and ***, respectively.

\begin{tabular}{|c|c|c|c|c|}
\hline & $(1)$ & $(2)$ & (3) & (4) \\
\hline Bank with more branches*NearTerm & $\begin{array}{c}0.005 \\
(0.601)\end{array}$ & & & \\
\hline Bank with more branches*LongTerm & $\begin{array}{c}-0.0292 \\
(-2.79)^{* *}\end{array}$ & & & \\
\hline Bank with fewer branches*NearTerm & $\begin{array}{c}0.061 * * * \\
(5.05)\end{array}$ & & & \\
\hline Bank with fewer branches*Long Term & $\begin{array}{c}0.077 * * * \\
(5.35)\end{array}$ & & & \\
\hline Contract with fewer covenants* NearTerm & & $\begin{array}{l}0.017^{*} \\
(1.843)\end{array}$ & & \\
\hline Contract with fewer covenants* LongTerm & & $\begin{array}{c}-0.006 \\
(-0.493)\end{array}$ & & \\
\hline Contract with more covenants* NearTerm & & $\begin{array}{c}0.042^{* * *} \\
(3.105)\end{array}$ & & \\
\hline Contract with more covenants* LongTerm & & $\begin{array}{c}0.045^{* * *} \\
(2.748)\end{array}$ & & \\
\hline Out-of-state merger* NearTerm & & & $\begin{array}{c}0.005 \\
(0.681)\end{array}$ & \\
\hline Out-of-state merger* LongTerm & & & $\begin{array}{c}-0.020 * * \\
(-2.148)\end{array}$ & \\
\hline In-state merger*NearTerm & & & $\begin{array}{c}0.085^{* * *} \\
(3.941)\end{array}$ & \\
\hline In-state merger*LongTerm & & & $\begin{array}{c}0.105^{* * *} \\
(4.350)\end{array}$ & \\
\hline Contract with low remaining maturity* NearTerm & & & & $\begin{array}{c}0.036^{* * *} \\
(4.008)\end{array}$ \\
\hline Contract with low remaining maturity* LongTerm & & & & $\begin{array}{c}0.026^{* *} \\
(2.295)\end{array}$ \\
\hline Contract $w /$ high remaining maturity* NearTerm & & & & $\begin{array}{c}0.009 \\
(0.755)\end{array}$ \\
\hline Contract $w /$ high remaining maturity* LongTerm & & & & $\begin{array}{c}-0.001 \\
(-0.056)\end{array}$ \\
\hline
\end{tabular}


Borrowers with low \%BankLoan*NearTerm

Borrower with low \%BankLoan*LongTerm

Borrower with high \%BankLoan*NearTerm

Borrower with high \%BankLoan*LongTerm

Control variables included

Contract-bank fixed-effects included

Quarter fixed-effects included

Observations

Adj R-squared

\begin{tabular}{ccccc} 
Yes & Yes & Yes & Yes & Yes \\
Yes & Yes & Yes & Yes & Yes \\
Yes & Yes & Yes & Yes & Yes \\
117,505 & 98,303 & 118,269 & 118,269 & 116,798 \\
0.733 & 0.728 & 0.733 & 0.732 & 0.730 \\
\hline
\end{tabular}




\section{Table 7: Effects of Bank Mergers on Borrowers Financing}

This table presents evidence on the effects of bank mergers on borrowers' financing arrangement. MERGER equals 1 for up to four years after the completion of the contracts for contracts experiencing mergers and zero for up to three years prior to the announcement of the merger. The dependent variables examined are: (1) natural logarithm of the total credit available under the most recent contract (LOGTOTCREDIT), (ii) natural logarithm of the total outstanding bond issued by borrowers, and (iii) an indicator variable that equals 1 if the relationship has been terminated. All regressions include contract-fixed effects, year-fixed effects, and time-varying controls including: (i) logarithm of the book value of total assets ( $\log ($ assets)), (ii) Leverage ratio measured as the book value of the total long-term debt divided by the total book value of assets (Leverage), (iii) annual sales growth (Sales growth), (iv) cash scaled by total assets (Cash), (v) Operating income before depreciation scaled by total assets (ROA), and (vi) Altman's (1968) Z-score (Z-score). All covariates are measured with a one-year lag to the dependent variables. T-statistics, reported in parentheses, are calculated based on robust standard errors obtained by clustering at the firm level. Statistical significance (two-sided) at the $10 \%, 5 \%$, and $1 \%$ level is denoted by $*, * *$, and ${ }^{* * *}$, respectively.

(1)

\begin{tabular}{lccc} 
VARIABLES & Log (total credit) & Log (total bond issuance) & I(termination) \\
\hline & & & \\
MERGER & $-0.086^{* * *}$ & $0.093^{* *}$ & $0.103^{* * *}$ \\
Log(assets) & $(-4.885)$ & $(2.104)$ & $(10.348)$ \\
& $0.591^{* * *}$ & $0.803^{* * *}$ & $-0.048^{* * *}$ \\
Leverage & $(29.787)$ & $(17.143)$ & $(-7.068)$ \\
& $0.257^{* * *}$ & $1.277^{* * *}$ & -0.010 \\
Sales growth & $(4.255)$ & $(8.150)$ & $(-0.526)$ \\
& $0.139^{* * *}$ & $0.319 * * *$ & $-0.024^{* * *}$ \\
Cash & $(5.927)$ & $(8.394)$ & $(-3.612)$ \\
& $-0.711^{* * *}$ & -0.030 & $0.088^{* * *}$ \\
ROA & $(-7.148)$ & $(-0.162)$ & $(2.665)$ \\
& 0.103 & -0.127 & -0.044 \\
Z-score & $(1.284)$ & $(-0.894)$ & $(-1.576)$ \\
& $-0.147^{* * *}$ & $-0.350^{* * *}$ & 0.012 \\
& $(-5.715)$ & $(-6.273)$ & $(1.459)$ \\
Contract-fixed effects included & Yes & & \\
Year-fixed effects included & Yes & Yes & Yes \\
Observations & 97,767 & 118,714 & Yes \\
Adj R-squared & 0.911 & 0.845 & 105,351 \\
\hline
\end{tabular}




\section{Table 8: Changes in financing patterns and disclosure}

This table presents evidence on the correlation between borrowers' disclosure response following bank mergers and changes in their financing arrangements. Dependent variable CONF_CALL is an indicator for whether the firm holds a conference call during a fiscal quarter. Coefficient estimates are obtained by estimating an augmented version of Eqn. (1) that includes the partition variable and its interaction with the MERGER dummy as additional covariates. Partition variables examined are: (i) an indicator for changes in the borrower's total bond financing where $\mathrm{I}(\Delta \mathrm{Bond}>0)$ is set to 1 if the average amount of bond financing in the post-merger periods is higher than that in the pre- merger periods, and 0 otherwise. $\mathrm{I}(\Delta$ Bond $\leq 0)$ is defined analogously. And (ii) an indicator for changes in the borrower's total bank financing where $\mathrm{I}(\Delta$ BankCredit $>0)$ is set to 1 if the average amount of bank financing in the post-merger periods is higher than that in the pre- merger periods, and 0 otherwise. I $(\Delta$ BankCredit $\leq 0)$ is defined analogously. All specifications include contract-bank and quarter fixed-effects. For brevity, coefficient estimates on control variables are omitted. All control variables are defined in the Appendix. T-statistics, reported in parentheses, are calculated based on robust standard errors obtained by clustering at the firm level. Statistical significance (two-sided) at the 10\%, $5 \%$, and $1 \%$ is denoted by $* * *$, and $* * *$, respectively.

\begin{tabular}{lcc}
\hline VARIABLES & $(1)$ & $(2)$ \\
\hline MERGER * I $(\Delta$ Bond $\leq 0)$ & $0.024^{* *}$ & \\
MERGER * I $(\Delta$ Bond $>0)$ & $(2.484)$ & \\
& $0.051^{* * *}$ & \\
MERGER * I $(\Delta$ BankCredit $\leq 0)$ & $(4.372)$ & $0.041^{* * *}$ \\
& & $(3.747)$ \\
MERGER * I $(\Delta$ BankCredit $>0)$ & & $0.039^{* * *}$ \\
& & $(3.226)$ \\
Differences in coefficients & & \\
& $0.027^{* *}$ & -0.001 \\
Control variables included & $(1.985)$ & $(-0.090)$ \\
Contract-bank fixed-effects included & & \\
Quarter fixed-effects included & Yes & Yes \\
Observations & Yes & Yes \\
Adj R-squared & Yes & Yes \\
\hline
\end{tabular}




\section{Table 9: Alternative Measures of Firm Disclosure}

This table presents evidence on the effect of lending bank's merger activity on alternative measures of borrower's disclosure based on earnings forecasts. The sample of earnings forecasts spans the period 1995 to 2009 and contains a maximum of 143,679 contract-bank-quarter observations. I(Earnings Forecast) is a dummy variable for whether the firm issues an earnings forecast in the quarter; Forecast Precision is a measure of forecast precision following the algorithm in Armstrong, et al. (2014): a forecast's precision is coded as 4 for point estimates, 3 for range estimates, 2 for open-ended estimates, 1 for qualitative estimates, and 0 for no forecasts. All specifications include contract-bank and quarter fixed-effects. All control variables are defined in the Appendix. T-statistics, reported in parentheses, are calculated based on robust standard errors obtained by clustering at the firm level. Statistical significance (two-sided) at the $10 \%, 5 \%$, and $1 \%$ level is denoted by $* * *$, and $* * *$, respectively.

\begin{tabular}{|c|c|c|}
\hline VARIABLES & $\begin{array}{c}(1) \\
\text { I(Earnings Forecast) }\end{array}$ & $\begin{array}{c}(2) \\
\text { Forecast Precision } \\
\end{array}$ \\
\hline Merger & $\begin{array}{l}0.021 * * \\
(2.537)\end{array}$ & $\begin{array}{c}0.066^{* *} \\
(2.410)\end{array}$ \\
\hline Log(assets) & $\begin{array}{c}0.080 * * * \\
(5.366)\end{array}$ & $\begin{array}{c}0.238 * * * \\
(5.147)\end{array}$ \\
\hline $\mathrm{B} / \mathrm{M}$ & $\begin{array}{c}0.034 \\
(1.238)\end{array}$ & $\begin{array}{c}0.086 \\
(1.010)\end{array}$ \\
\hline Leverage & $\begin{array}{l}-0.088 * * \\
(-2.521)\end{array}$ & $\begin{array}{l}-0.246 * * \\
(-2.278)\end{array}$ \\
\hline $\mathrm{R} \& \mathrm{D}$ & $\begin{array}{c}0.022 \\
(0.059)\end{array}$ & $\begin{array}{c}0.574 \\
(0.434)\end{array}$ \\
\hline Log(segments) & $\begin{array}{c}0.015 \\
(1.224)\end{array}$ & $\begin{array}{c}0.056 \\
(1.446)\end{array}$ \\
\hline Log(age) & $\begin{array}{l}-0.052^{* *} \\
(-2.250)\end{array}$ & $\begin{array}{l}-0.152 * * \\
(-2.006)\end{array}$ \\
\hline Volatility & $\begin{array}{l}-0.142 * * \\
(-2.139)\end{array}$ & $\begin{array}{l}-0.425^{* *} \\
(-2.006)\end{array}$ \\
\hline Log(price) & $\begin{array}{c}0.038 * * * \\
(4.102)\end{array}$ & $\begin{array}{c}0.122^{* * *} \\
(4.347)\end{array}$ \\
\hline Return & $\begin{array}{l}-0.078 * * * \\
(-10.102)\end{array}$ & $\begin{array}{c}-0.235 * * * \\
(-9.885)\end{array}$ \\
\hline $\begin{array}{l}\text { Contract-bank fixed effects included } \\
\text { Quarter fixed-effects included }\end{array}$ & $\begin{array}{l}\text { Yes } \\
\text { Yes }\end{array}$ & $\begin{array}{l}\text { Yes } \\
\text { Yes }\end{array}$ \\
\hline $\begin{array}{l}\text { Observations } \\
\text { Adj R-squared }\end{array}$ & $\begin{array}{c}143,679 \\
0.540\end{array}$ & $\begin{array}{c}143,679 \\
0.529\end{array}$ \\
\hline
\end{tabular}




\section{Appendix: Variable definitions}

\section{A.1. Disclosure measures}

\begin{tabular}{|l|l|}
\hline Variable name & Description \\
\hline CONF_CALL & CONF_CALL is an indicator for holding a conference call during a quarter. \\
\hline I(Earnings Forecast) & $\begin{array}{l}\text { I(Earnings Forecast) is an indicator for the issuance of a management forecast during a } \\
\text { quarter. }\end{array}$ \\
\hline PRECISION & $\begin{array}{l}\text { PRECISION equals } 4 \text { for point forecasts, } 3 \text { for range forecasts, } 2 \text { for open-ended } \\
\text { forecasts, } 1 \text { for qualitative forecasts, and 0 for no forecasts. }\end{array}$ \\
\hline
\end{tabular}

\section{A.2. Merger variables}

\begin{tabular}{|l|l|}
\hline Variable Name & Description \\
\hline MERGER & $\begin{array}{l}\text { MERGER is a dummy variable that equals one for all contract-bank-quarter } \\
\text { observations after the completion of earliest merger involving the lead bank } \\
\text { during the contract period, and zero otherwise. }\end{array}$ \\
\hline ACQUIRER & $\begin{array}{l}\text { ACQUIRER is a dummy variable that equals one for all contract-bank-quarter } \\
\text { observations after the completion of earliest acquisition by the lead bank over } \\
\text { the contract period, and zero otherwise. }\end{array}$ \\
\hline TARGET & $\begin{array}{l}\text { TARGET is a dummy variable that equals one for all contract-bank-quarter } \\
\text { observations after the completion of the acquisition of the lead bank by another } \\
\text { bank, and zero otherwise. }\end{array}$ \\
\hline IN-STATE & $\begin{array}{l}\text { IN-STATE is a dummy variable that equals one if both the acquirer and the } \\
\text { target bank involved in a merger are headquartered in the same state, and zero } \\
\text { otherwise. }\end{array}$ \\
\hline
\end{tabular}

\section{A.3. Control variables in disclosure regressions}

All control variables have been constructed using information on financial reports from COMPUSTAT, analyst related information from IBES database, stock price information from CRSP database, and information on institutional ownership from Thomson financial 13f institutional holdings database.

\begin{tabular}{|l|l|}
\hline Variable Name & Description \\
\hline LOG(ASSETS) & LOG(ASSETS) is the natural logarithm of the book value of total assets. \\
\hline LEVERAGE & $\begin{array}{l}\text { LEVERAGE is the book value of the total long-term debt divided by the total } \\
\text { book value of assets. }\end{array}$ \\
\hline$B / M$ & $\begin{array}{l}\text { B/M is the ratio of the book value of total assets to the sum of the firm's market } \\
\text { capitalization and book value of liabilities. }\end{array}$ \\
\hline RETURN & RETURN is the quarterly stock return of the borrower. \\
\hline VOLATILITY & $\begin{array}{l}\text { VOLATILITY } Y_{t} \text { is the standard deviation of monthly stock returns over a } 2 \text { year } \\
\text { period with a requirement of at least 12 observations. }\end{array}$ \\
\hline$L O G(S E G M E N T S)$ & $\begin{array}{l}\text { LOG(SEGMENTS) is the natural logarithm of the number of business segments } \\
\text { in which a firm operates. }\end{array}$ \\
\hline$L O G(A G E)$ & $\begin{array}{l}\text { LOG(AGE) is the natural logarithm of the number of years for which a firm } \\
\text { appears in the CRSP database. }\end{array}$ \\
\hline$L O G(P R I C E)$ & $L O G(P R I C E)$ is the natural logarithm of the borrower's stock price. \\
\hline$R \& D$ & $\begin{array}{l}R \& D \text { is the research and development expenditure scaled by total book value of } \\
\text { assets. }\end{array}$ \\
\hline
\end{tabular}




\section{A.4. Loan contract variables}

All control variables have been constructed using information on financial reports from DealScan and COMPUSTAT.

\begin{tabular}{|l|l|}
\hline Variable Name & Description \\
\hline \%BANKLOAN & $\begin{array}{l}\text { \%BANKLOAN is the ratio of total contract amount to the borrower's book value } \\
\text { of total assets. }\end{array}$ \\
\hline $\begin{array}{l}\text { REMAINING } \\
\text { MATURITY }\end{array}$ & $\begin{array}{l}\text { REMAINING MATURITY is the number of days between the merger effective } \\
\text { date and the end date of the contract. }\end{array}$ \\
\hline \# OF COVENANTS & \# OF COVENANTS is the number of covenants specified in the loan contract. \\
\hline \# OF BANKING & \#BANKING RELATIONSHIP is the number of lead banks for each borrower in \\
RELATIONSHIP & given year. \\
\hline $\begin{array}{l}\text { MULTIPLE } \\
\text { RELATIONSHIPS }\end{array}$ & $\begin{array}{l}\text { MULTIPLE RELATIONSHIPS is an indicator variable for whether the borrower } \\
\text { has more than one lead banks. }\end{array}$ \\
\hline
\end{tabular}

